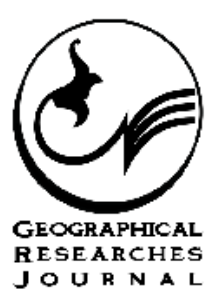

\title{
The Role of Urban Governance in the Urban Worn Texture RegenEration Process Case Study: District 12 of Tehran
}

\section{ART ICLE INFO}

\section{Article Type}

Original Research

\section{Authors}

Amini M. ${ }^{1} M A$,

Saremi HR.* $P h D$,

GHalibaf MB.H. ${ }^{2} P h D$
How to cite this article MB.H. The Role of Urban Governance in the Urban Worn Texture RegenEration Process Case Study: District 12 of Tehran. Geographical Researches Quarterly Journal.2018;33(3):202-217.
Amini M, Saremi HR, GHalibaf

\section{A B S T R A C T}

Introduction and Background The complications and problems of urban areas worn out are multifaceted and multidimensional in nature, and in each case they occur in a particular way. The decline in social and economic status, and the functional and physical dislocation of these tissues, together with the very severe deterioration in the quality of the urban environment, are among the reasons why policymakers and urban planners are required to provide management strategies and solutions in the face of related problems and challenges. One of these new approaches is the regeneration approach within the framework of urban governance.

Aims The purpose of this study is to assess the urban governance status in the process of rehabilitating urban environment of the 12th district of Tehran. This paper attempts to answer the question of how is the status of indexes dominated by the urban depreciated texture and also to evaluate the influence of governance on urban regeneration of urban old texture.

Methodology TResearch method is descriptive-analytical and in terms of purpose, is developmental. The unit of analysis is considered the head of household. The sample size was determined using the Cochran formula which is 383 people. To define the sample, random sampling was used at district level according to the number of inhabitants.

Library and field methods have been used to collect the required information. A questionnaire was used to collect field information. Descriptive and inferential statistics were used for analysis.

Conclusion Results show that among the indicators of urban governance, the index of justice and effectiveness and efficiency are the most, and the indicators of accountability and strategic insight have the lowest rank. In general, urban governance indicators in the 12th municipality district of Tehran are at a lower than average level. Also, governance is affected more from physical, economic and social indicators comparing to cultural and environmental indicators.

Keywords Prediction of Changes; Markov Chain Model; Cellular Automata; Bazangan Lake; Remote Sensing

\section{I T A T I O N L I N K S}

*Department of Urbanism, Faculty of Art \& Architecture,Tarbiat Modares University, Tehran, Iran ${ }^{1}$ Department of Urbanism, Faculty of Art \& Architecture,Tarbiat Modares University, Tehran, Iran ${ }^{2}$ Department of Political Geography , Faculty of Geography, Tehran University, Tehran, Iran

\section{*Correspondence}

Address: Tarbiat Modares University, Nasr Bridge, Jalal-Al-Ahmad Highway, Tehran, Iran.

Phone: -

Fax: -

saremi@modares.ac.ir

\section{Article History}

Received: September 05, 2018

Accepted: October 04, 2018

ePublished: December 09, 2018
[Adams \& Hastings; 2001] Urban renewal in Hong Kong: transition from development ...; [Aeeni \& Ardestani; 2009] Pyramid regeneration and people participation ...; [Ahmadpour, et al.; 2010] The evolution of the concept of urban ...; [Azimi Amoli,et al.; 2014] Renovation of urban textile tissues with a public ...; [Azimi Amoli \& Jamdar; 2016] Regeneration of worn-out urban textures ...; [Brenner; 2004] New state spaces: Urban governance and ...; [Copus; 2012] The role of local governance in ...; [Dert; 2000] By desing: Urban desing in the planning ...; [Fallahzadeh \& Mahmoudi; 2015] Prioritizing participatory policies in ...; [Habibi, et al.; 2007] Urban rehabilitation \& renovation in the old ...; [Hafeznia; 2009] An introduction to the research method in ...; [Hamzeyee, et al.; 2013] Good governance in the municipality of ...; [Kalantari Khalilabad \& Pourahmad; 2005] Models and techniques of renovation planning ...; [Kennedy; 2008] New forms of governance in Hyderabad: How urban ...; [Kotler; 1982] Marketing for nonprofit organizations ..; [Luda; 2006] E- compendium: Handbook E2, understanding large ...; [Magalhaes; 2004] Centres of excellence for urban regeneration ...; [Neto; 2007] Strategic planning of territorial image ...; [Nobari \& Rahimi; 2010] Good urban governance is an indispensable ...; [Nussbaumer \& Moulaert; 2004] Integrated area development and social ...; [ObengOdoom; 2013] Governance for pro-poor urban development ...; [Rahnama \& Asadi; 2014] Determination of the status of good urban ...; [Rahnamaei \& Keshavarz; 2010] A study of the pattern of good governance and the ...; [Roberts \& Sykes; 2000] Urban regeneration: A handbook ...; [Roknoddin Eftekhari, et al.; 2011] The relationship between good governance ...; [Sabaqi; 2013] Compilation of the mechanism of urban regeneration ...; [Saraei; 1996] An introduction to research sampling ...; [Seo; 2002] Re-urbanisation in regenerated areas of Manchester ...; [Stone; 2004] It's more than the economy after ...; [Tosics; 2009] Dilemmas of integrated area-based urban ...; [UN-HABITAT; 2009] Urban governance index (UGI) a tool to measure ...; [Vranken; 2008] Cities and neighborhoods in ...; [Yung \& Chan; 2004] Local politics and governance ... 
Amini M. MA

Saremi H. PhD

Ghalibaf M. PhD

saremi@modares.ac.ir

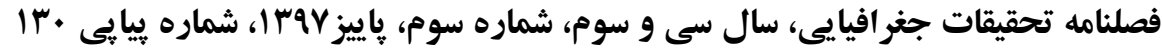

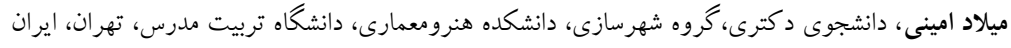

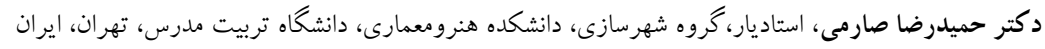

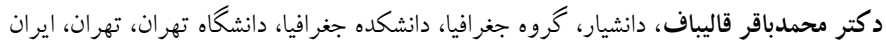

\section{جايكاه حكمروايى شهرى در فر آيند باز آفرينى بافت فرسوده شهرى مطالعه موردى: منطقه YI شهر تهران}

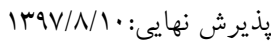

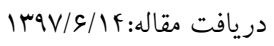

DOI: 10.29252/geores.33.3.202

جكيده

مقدمه: عوارض و مشكلات نواحى فرسوده شهرى، بنا به سرشت خود خِندوجهى و جِندبعدى هستند و در هر مورد به شكل خاصى بروز مىنمايد. افت منزلت اجتماعى و اقتصادى و نابسامانىهاى كاركردى و كالبدى اين بافتها به همراه افت بسيار شديد

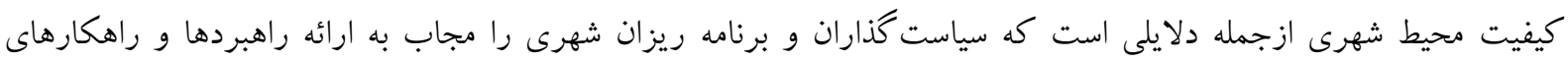

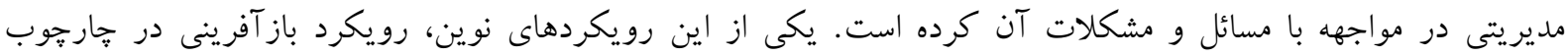
حكمروايى شهرى است.

اهداف: هدف اين يزوهش، ارزيابى جايگاه حكمروايى شهرى در فر آيند باز آفرينى بافت فرسوده شهرى منطقه rا شهر

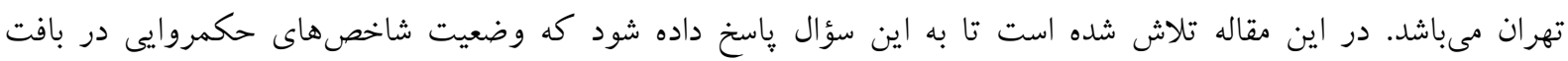

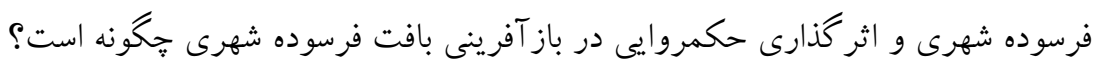
مواد و روشها: روش تحقيق در اين يزوهش از نوع توصيفى- تحليلى و به لحاظ هدف كاربردى - توسعهاى مىباشد و و

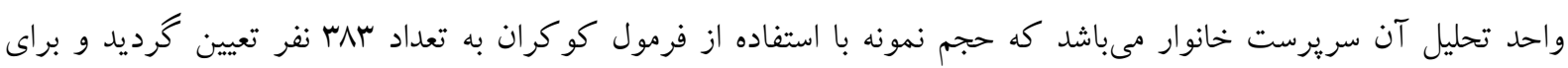

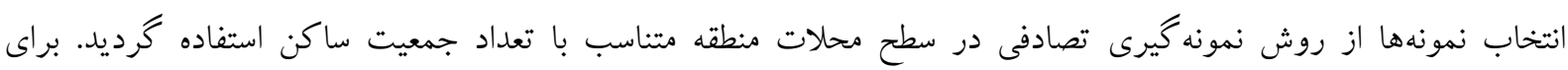

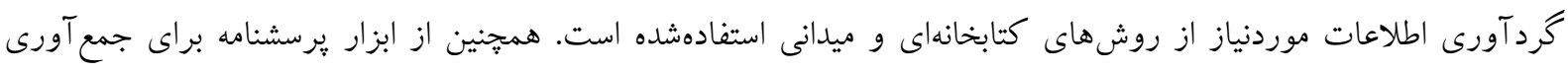
اطلاعات ميدانى استفاده گرديد. در راستاى تجزيهو تحليل از آمارهاى توصيفى و استنباطى استفاده گرديديد.

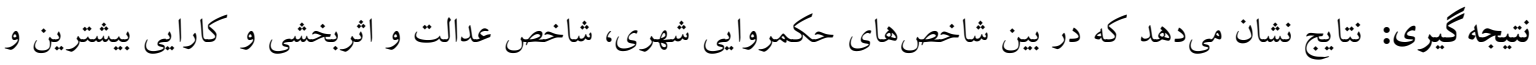

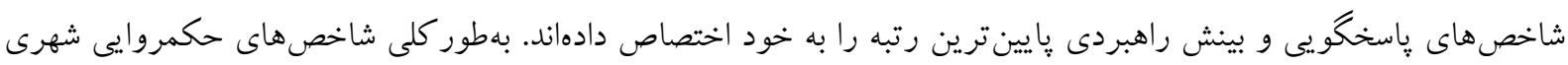

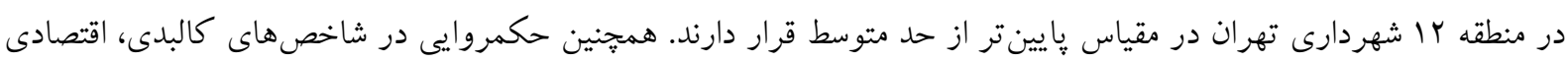

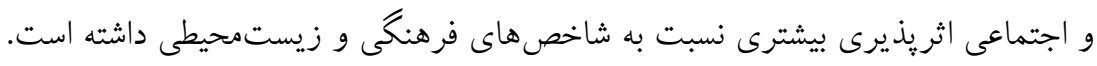

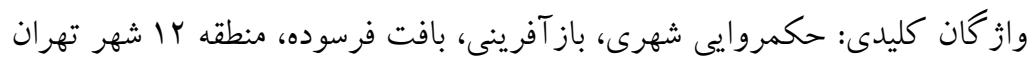

مقدمه الكُوى مديريت شهرى سنتى با شكل گيرى تحولات اجتماعى و سياسى و تغيير و تحولات در حوزه فناورىهاى اطلاعات و

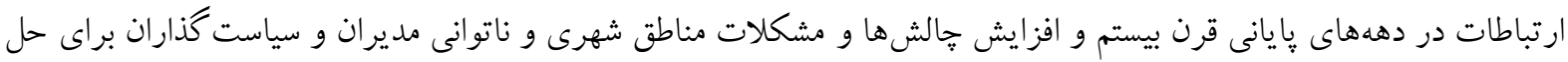


T.F.F يا كاهش آنها، مورد انتقادات وسيعى قرارگرفته است(Habibi, Pour Ahmad, \& Meshkini, 2007) در خنين شرايطى است

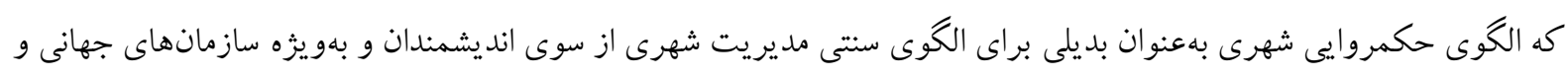

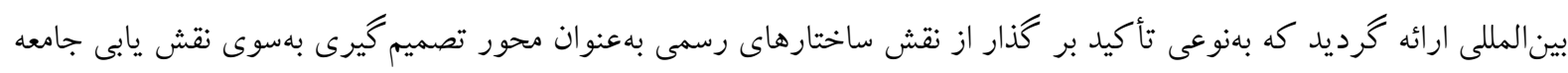
مدنى در اعمال حقوق دموكراتيك و انجام وظايف مىباشد (Azimi Amoli \& Jamdar, 2016)

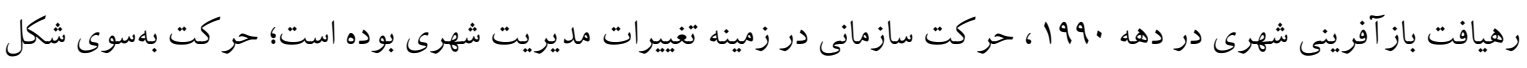

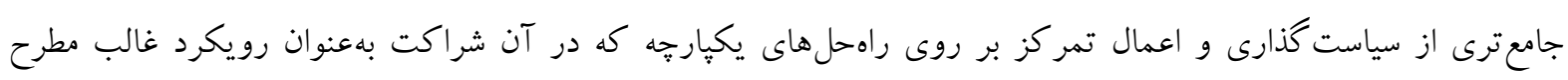

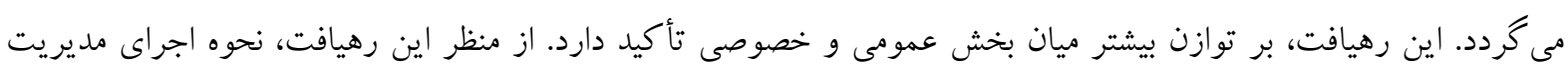

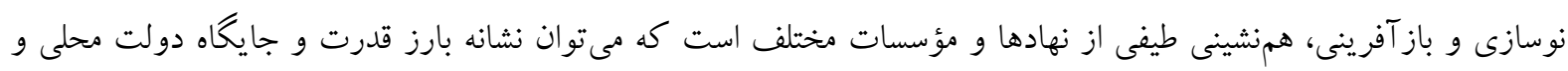

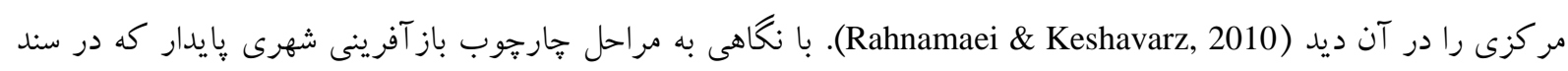

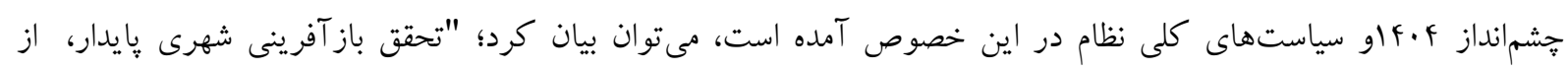

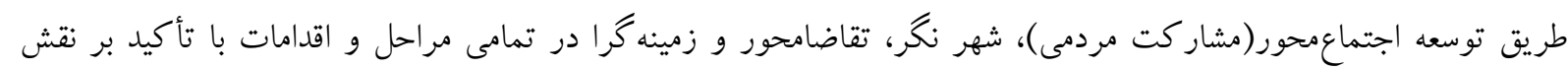

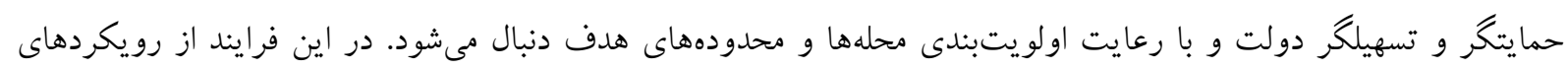

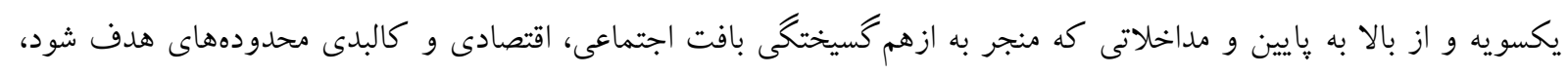

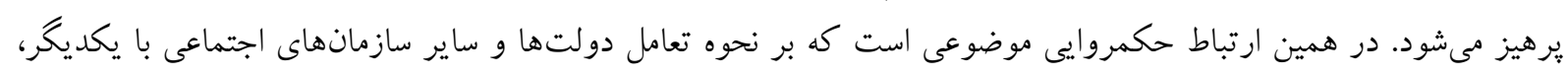

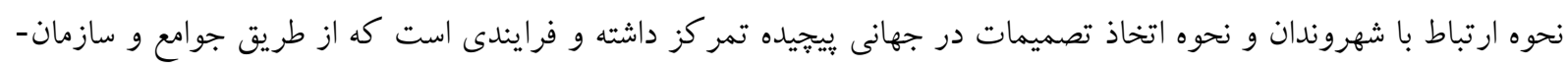

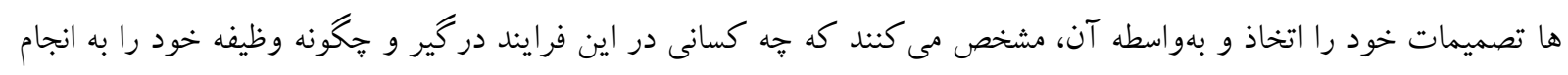

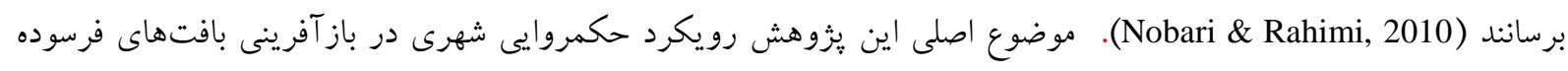

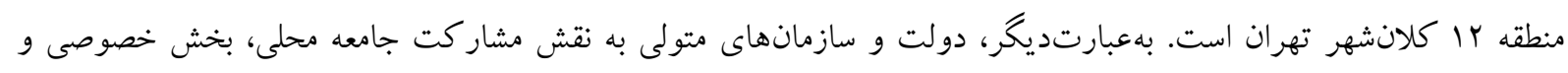

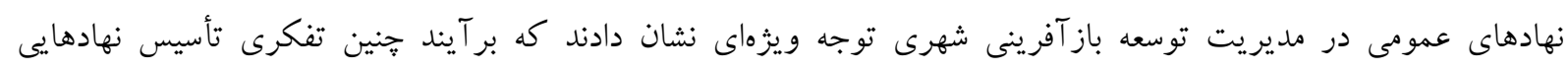

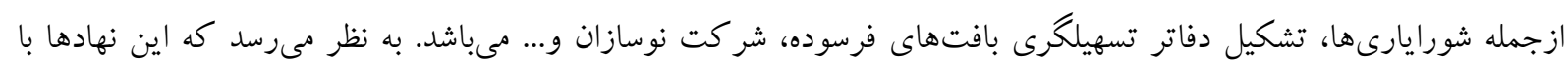

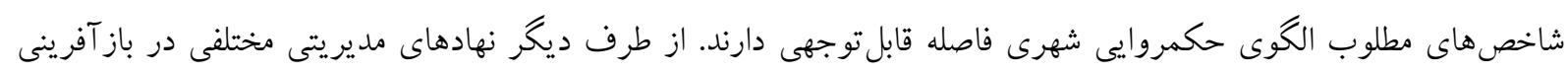

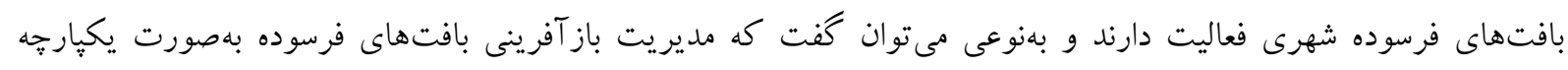

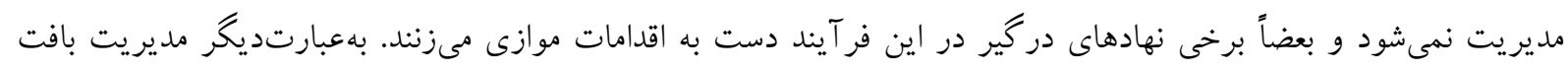

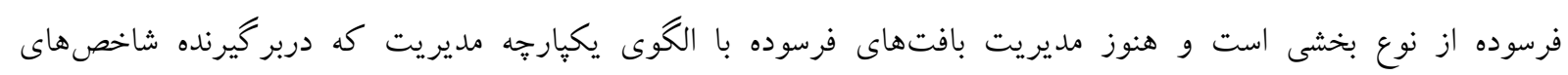

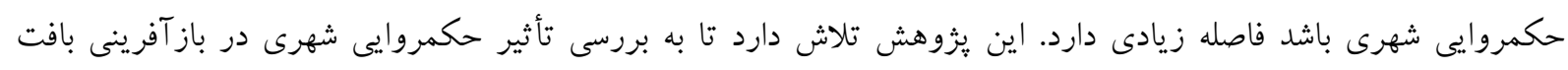

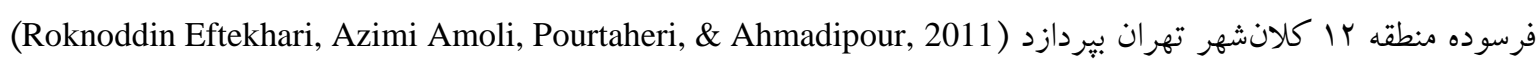
مباحث حكمروايى شهرى و باز آفرينى بافت فرسوده شهرى رويكردهاى نسبتاً جديدى در ادبيات برنامهريزى و

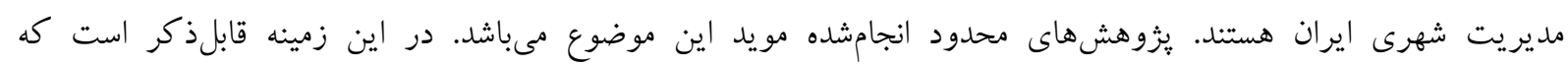

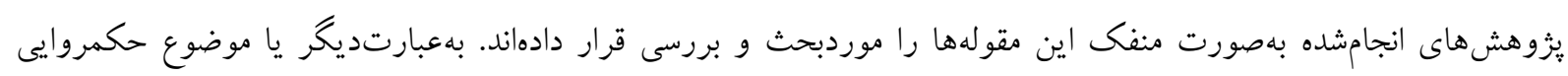

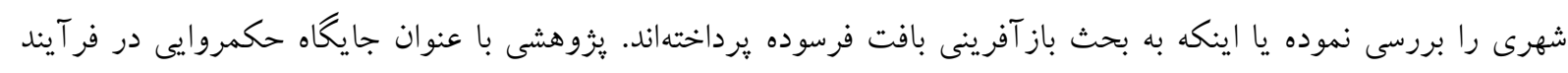

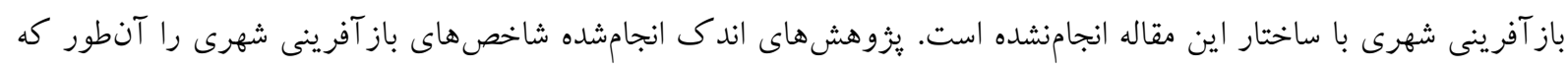

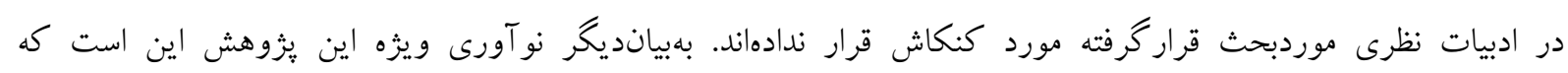


شاخصهاى باز آفرينى شهرى را در بستر باز آفرينى بافت فرسوده بررسى نموده و نقش شاخصهاى حكمروايى شهرى در ارتقاء شاخصهاى باز آفرينى شهرى را مورد ارزيابى قرار داده است.

\section{ييشينه يزو هش}

با توجه به اينكه تعداد يزوهش كمّى در ارتباط با با نقش حكمروايى شهرى در باز آفرينى شهرى انجامشده است، بنابراين

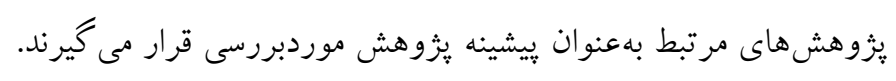

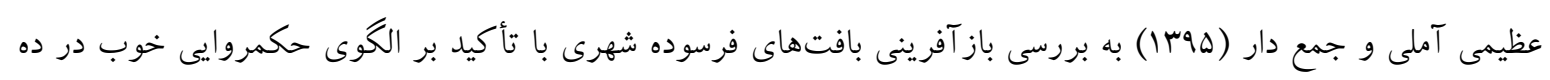

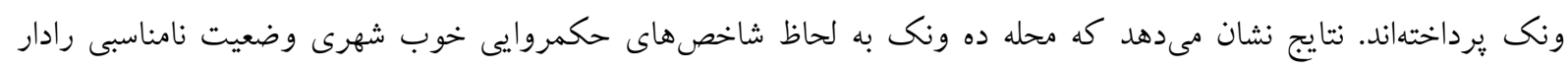

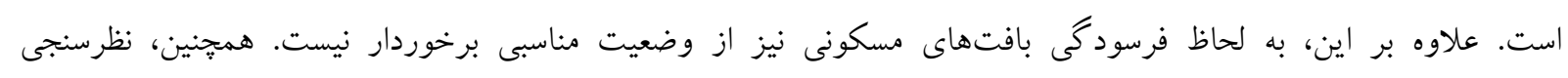

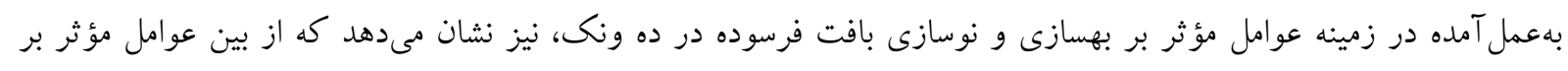

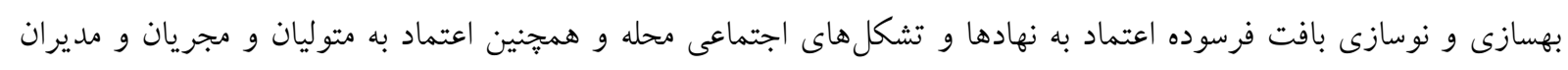

طرحهاى بهسازى و نوسازى ازنظر باسخخو يان داراى بيشترين تأثير بوده است (Azimi Amoli \& Jamdar, 2016).

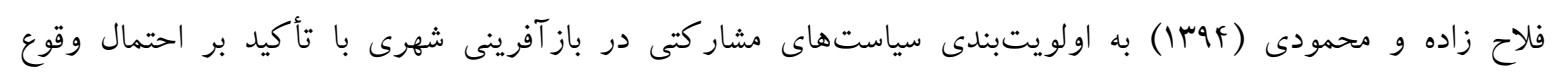

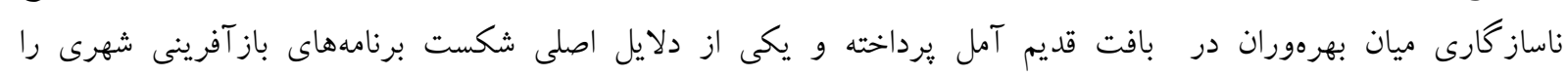

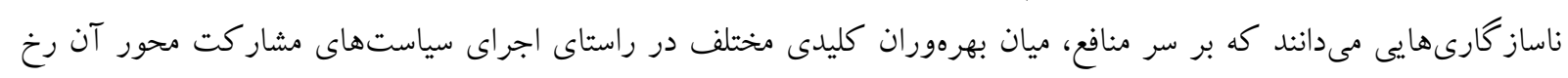

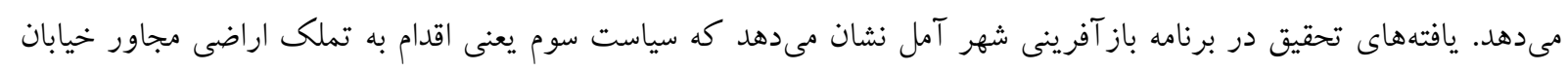

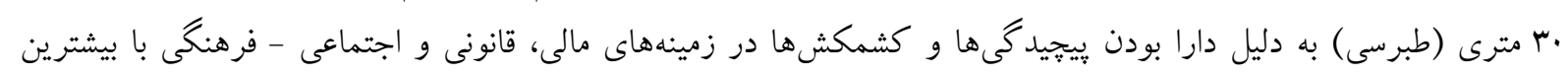

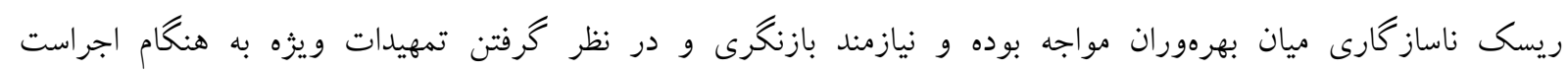

.(Fallahzadeh \& Mahmoudi, 2015)

صباغى (rara) در تحقيق به تدوين سازو كار به كارگيرى بازآفرينى شهرى در مواجهه با بافتهاى فرسوده محله جولان

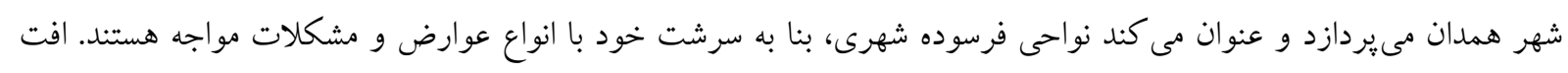

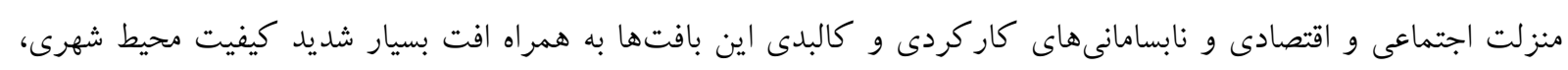

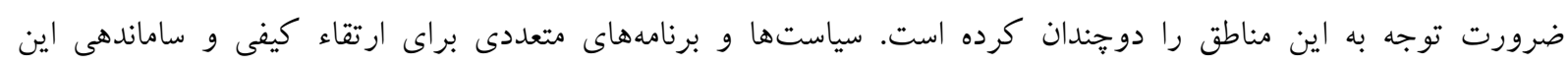

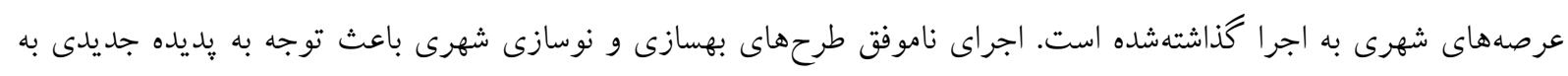

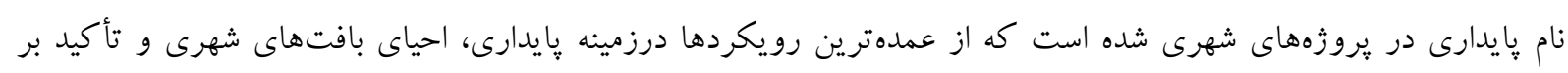

رويكرد باز آفرينى است (Sabaqi, 2013).

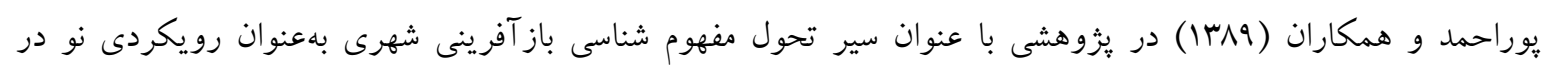

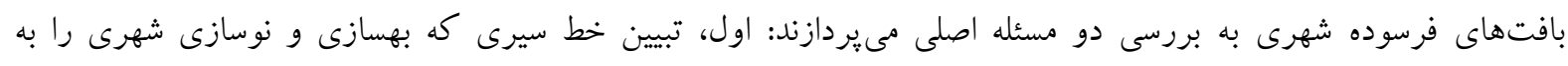

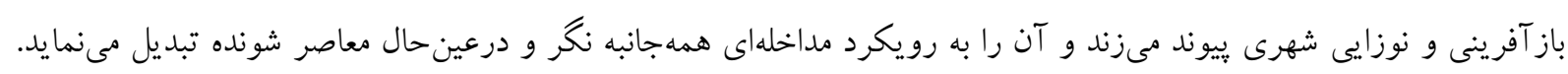

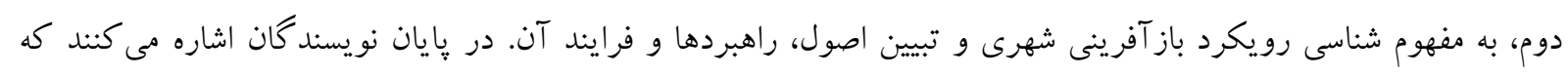

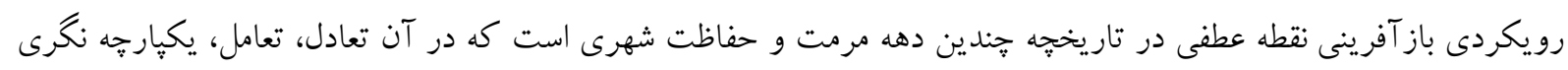

بى سابقهاى خودنمايى مى كند (Ahmadpour, Habibi, \& Keshavarz, 2010).

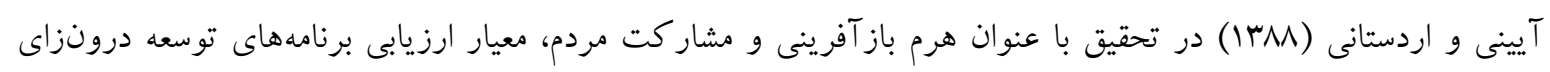

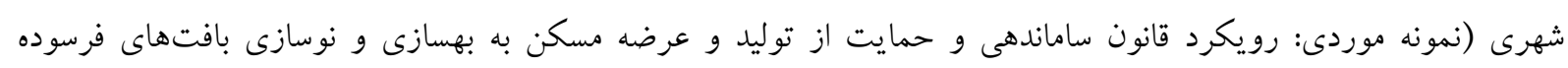




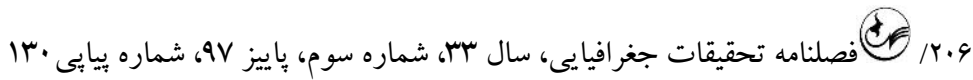
شهرى) به اين موضوع مى يردازند كه بهسازى و نوسازى بافتهاى فرسوده شهرى در گارجوب سياست توسعه درونى، بر

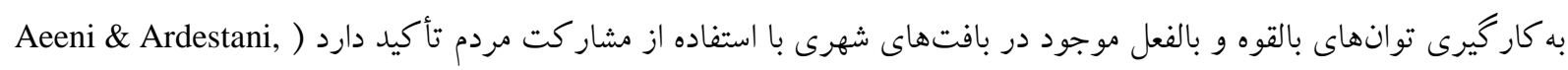

\section{روش شناسى :زو هش}

تحقيق حاضر با استفاده از روش توصيفى- تحليلى به مطالعه جايگاه حكمروايى شهرى در باز آفرينى بافت فرسوده

شهرى منطقه rا شهر تهران يرداخته است. جامعه آمارى تحقيق حاضر ساكنان بافت فرسوده محله إى شهرى منطقه Y شهر تهران هستند كه تعداد آنها بر اساس آمارهاى سازمان نوسازى شهر تهران 9.9.9 نقو مىباشد. حجم نمونه محاسبهشده براى ساكنان بر اساس فرمول \كو كران') با سطح اطمينان هو درصد و ييش بر آورد واريانس هب درصد و دقت احتمالى مطلوب هـ درصد، تعداد بهץ ساكن است. براى انتخاب نمونه از روش نمونه گيرى تصادفى ساده استفاده شد و بهطور مستقيم از آنها

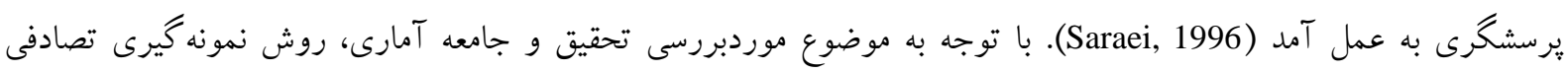
است. انتخاب و تبيين مؤلفهاى يزووهش با توجه به ادبيات موضوع و مشاهدات ميدانى صورت گرفت. بهطورى كه مؤلفه اثر كذار( حكمروايى شهرى) در باز آفرينى بافت فرسوده با توجه به 9 معيار و لهو مؤلفه سنجيده شده است(جدول ()).

\begin{tabular}{|c|c|c|}
\hline كويه & شاخص & مستقل \\
\hline 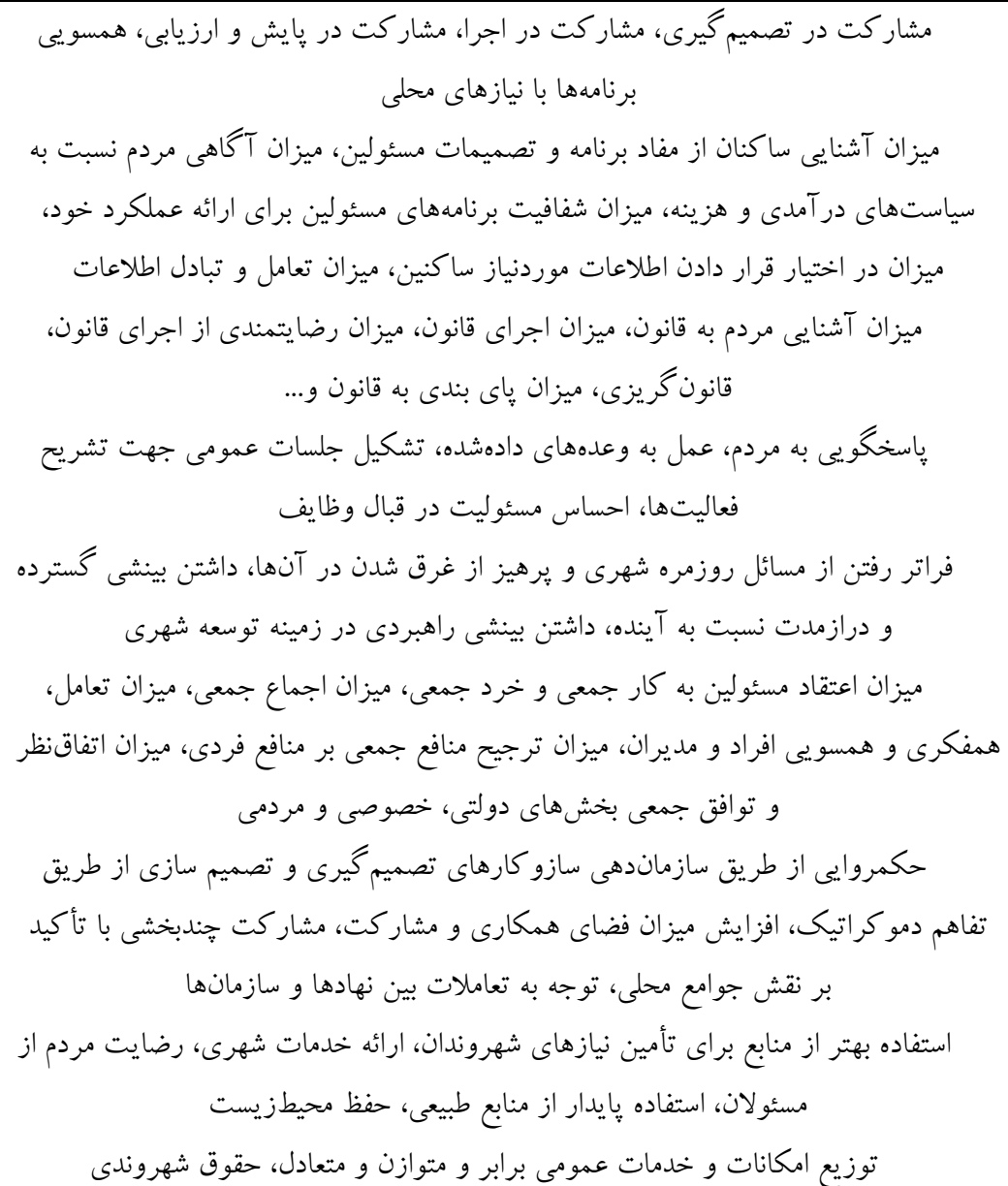 & 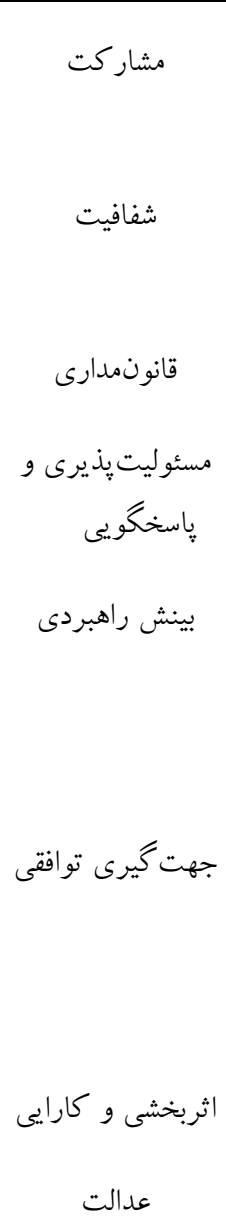 & $\begin{array}{l}\hat{n} \\
\hat{\phi} \\
\hat{\varepsilon} . \\
\hat{n} \\
\xi \\
\xi \\
\xi\end{array}$ \\
\hline
\end{tabular}

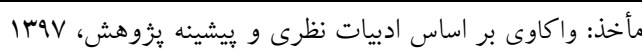

${ }^{1}$ Cochran 
جدول r - مؤلفهاى سنجش مؤلفه باز آفرينى شهرى در ارتباط با حكمروايى شهرى

\begin{tabular}{|c|c|c|}
\hline كويه & شاخص & وابسته \\
\hline 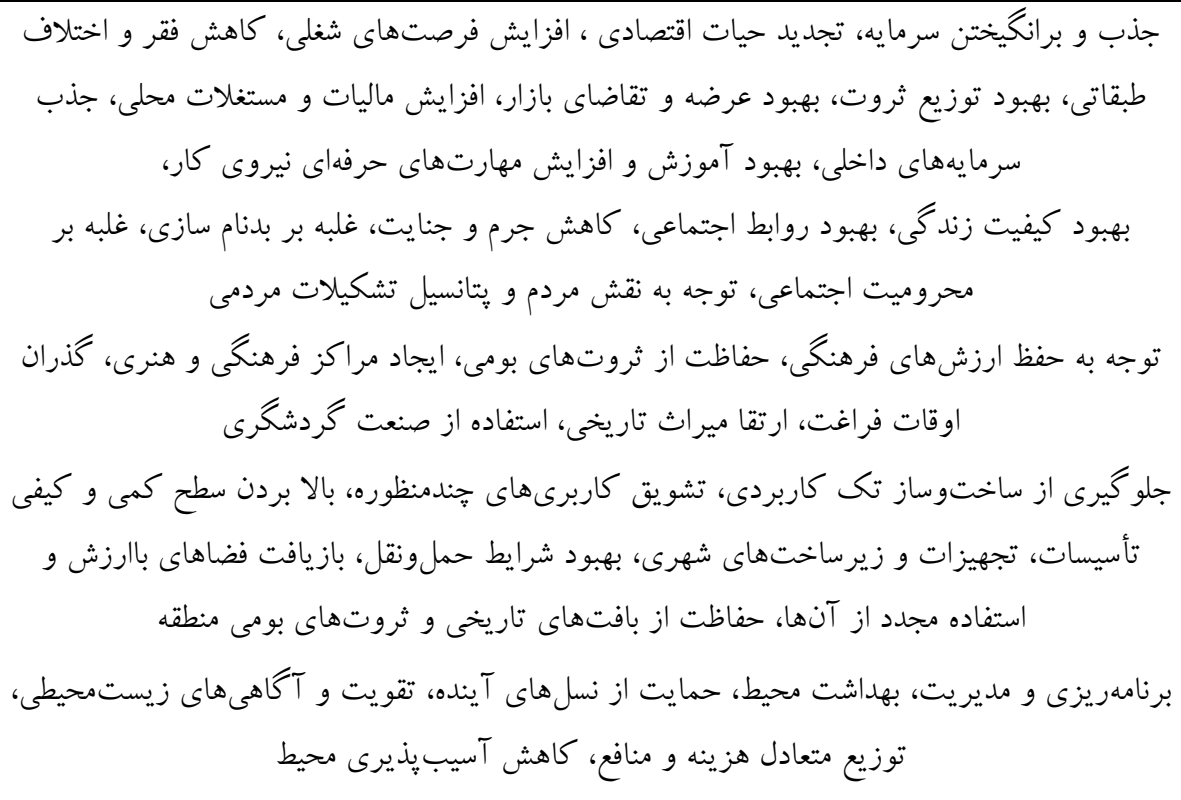 & كالبدى & باز بافت آفرينى \\
\hline
\end{tabular}

مأخذ: واكاوى بر اساس ادبيات نظرى و بيشينه يزوهش، Irav

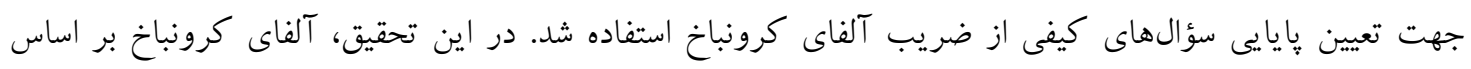

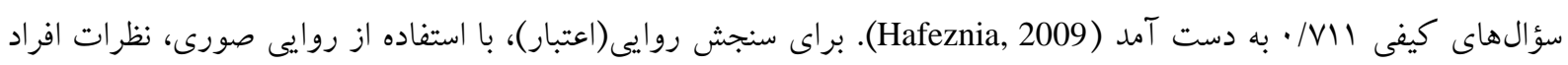

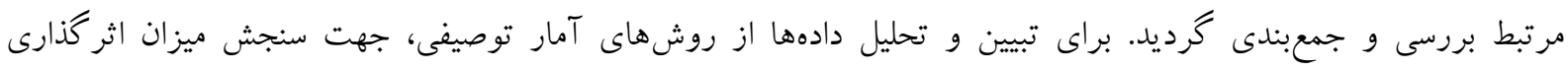

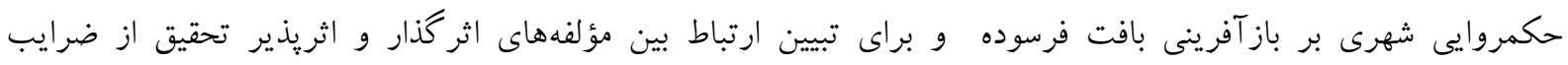

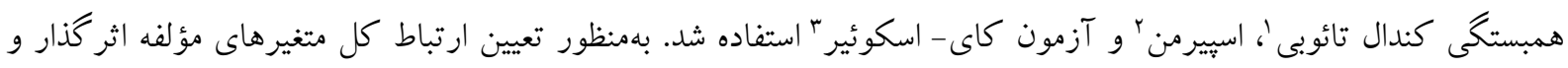

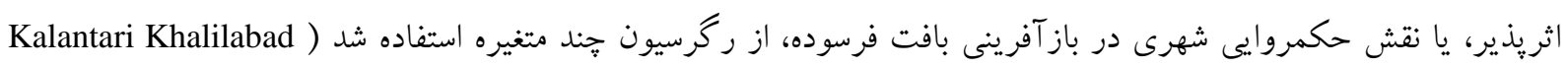

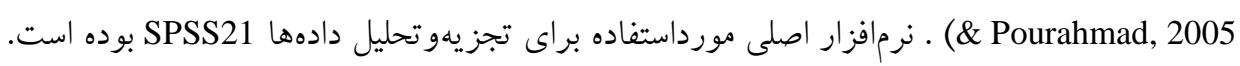

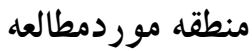

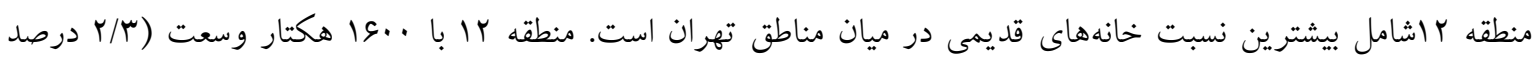

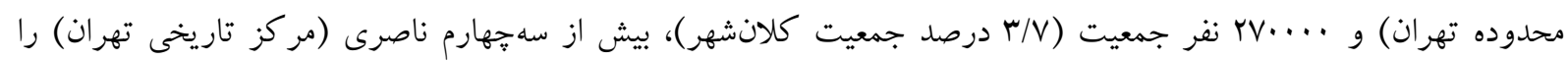

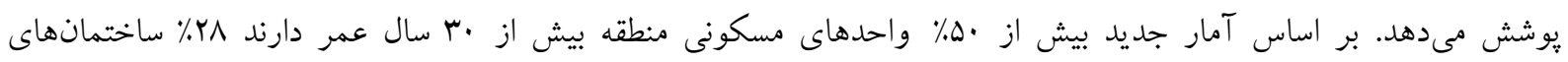

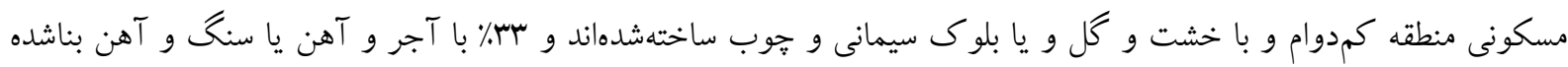

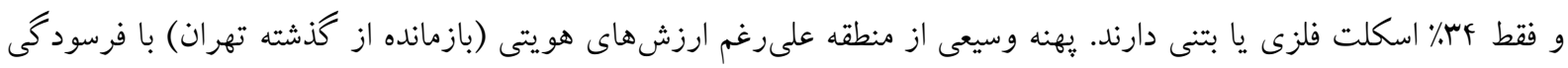

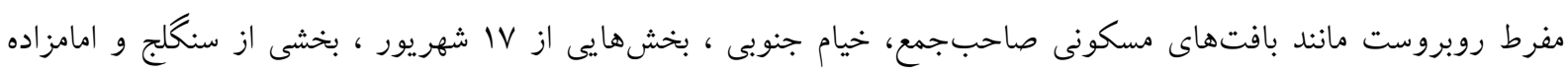

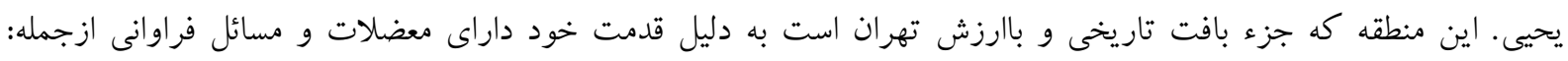

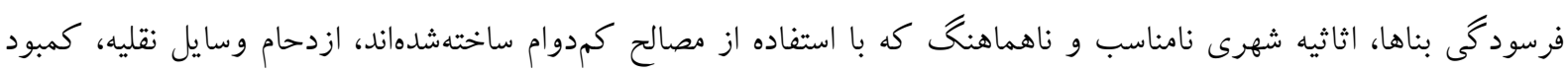

1 Kendall's tau_b 


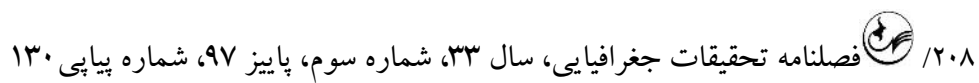
فضاى سبز، سيماى آشفته شهرى، بدنه سازى ناهماهنگ خيابانهاى اصلى و نامناسب بودن زيرساختها و خدمات شهرى

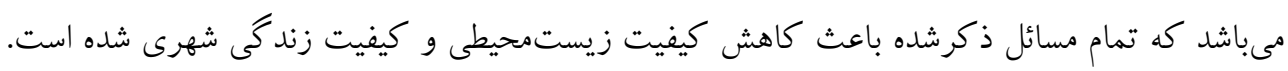

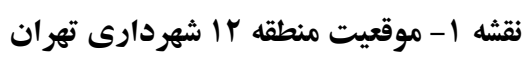

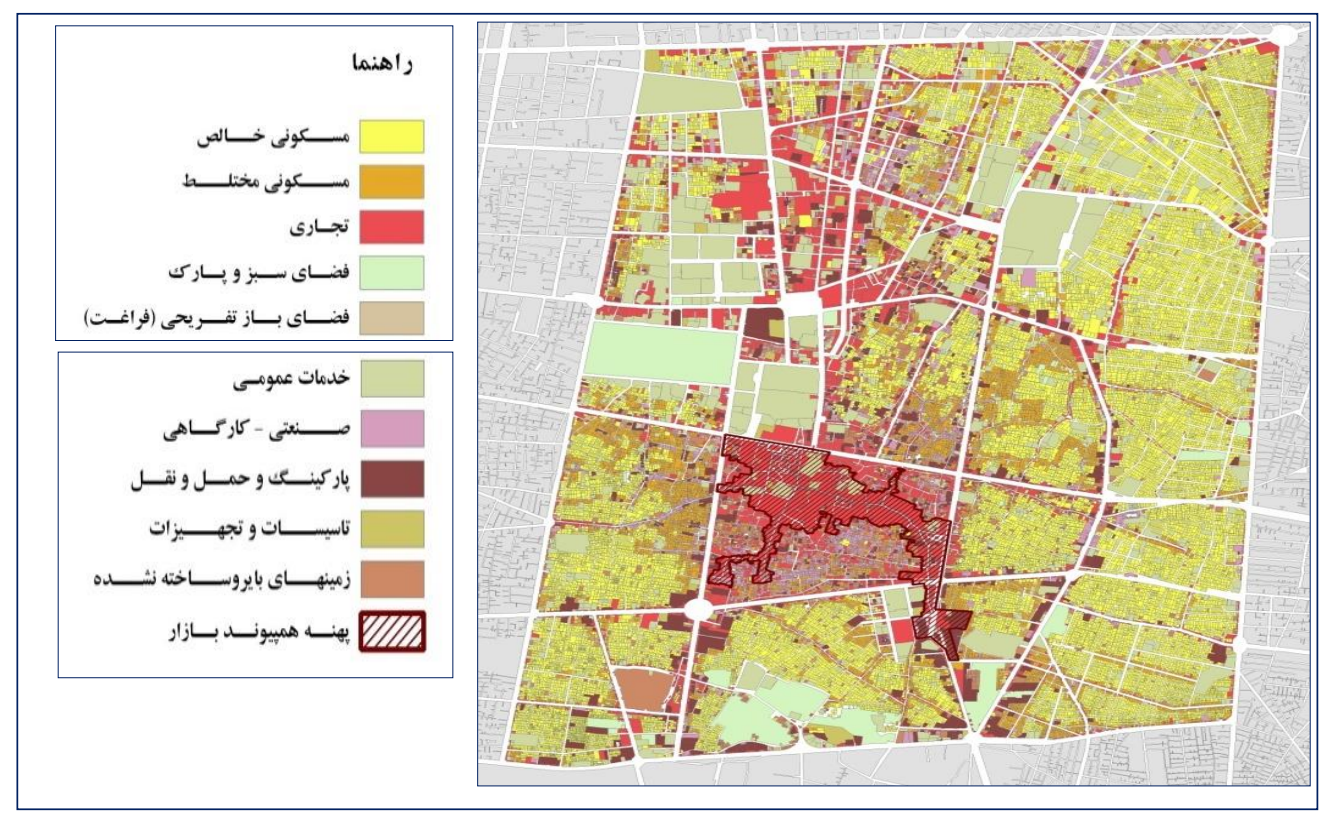

مبانى نظرى يزوهش اصطلاح بازآفرينى' شهرى عموماً به تحول در محيطزيست شهرى در جهت سازماندهى مسائل شهرى اشاره دارد (Adams \& Hastings, 2001)

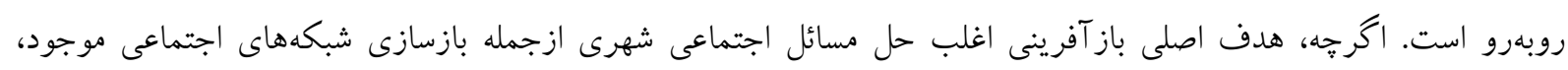

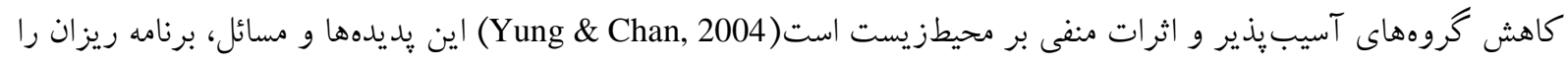

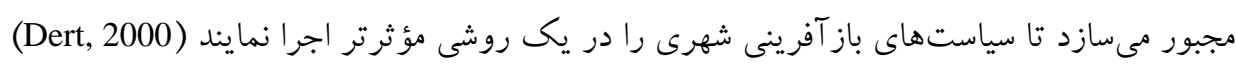

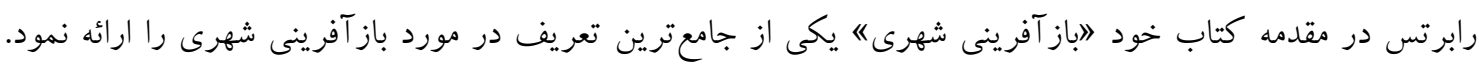

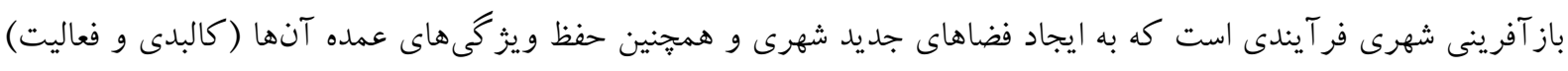

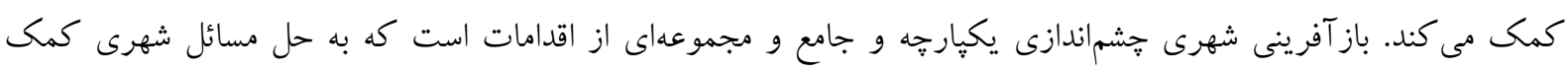

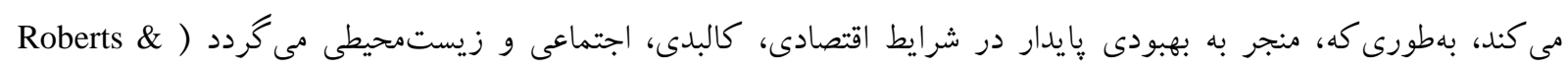

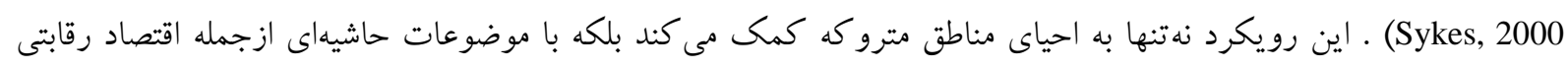

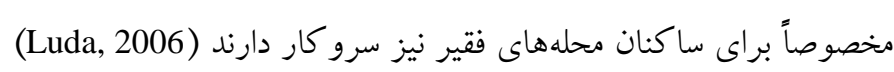
ابعاد باز آفرينى شهرى بازآفرينى كالبدى: در راستاى ارزيابى عناصر كالبدى شهر انجام مى گردد و در جستوجنى تهرى محدوديتها و قدرت

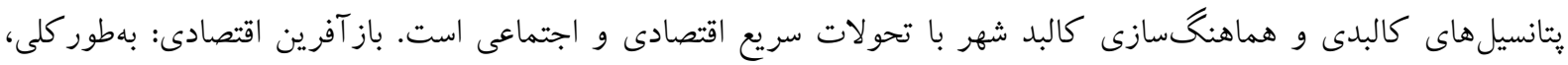


باز آفرينى پايدار اقتصادى شامل سياستها و اهدافى ازجمله جذب سرمايههاى محلى، تشويق خوداشتغالى، ايجاد مشاغل پارهوقت

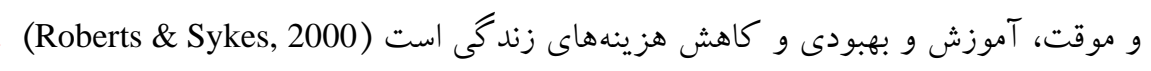

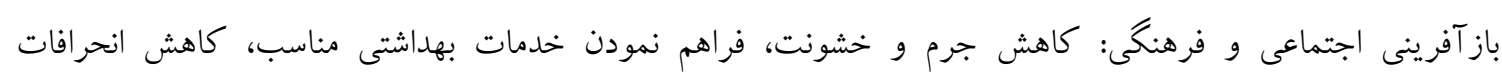

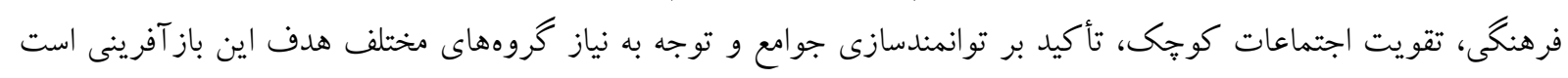

(Seo, 2002)

الكوى مديريت شهرى سنتى با شكل گيرى تحولات اجتماعى و سياسى و تغيير و تحولات در حوزه فناورىهاى اطلاعات و

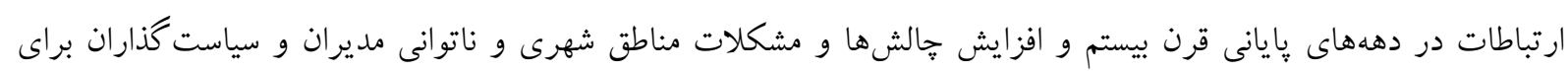

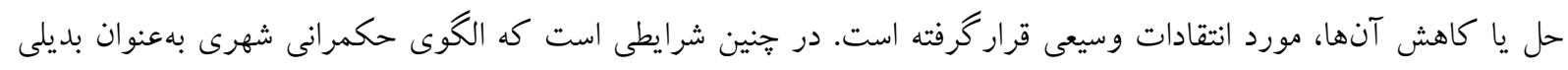

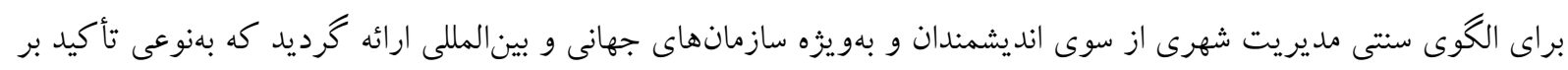

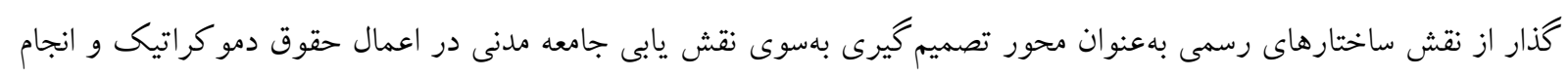

وظايف مىباشد (Rahnamaei \& Keshavarz, 2010)

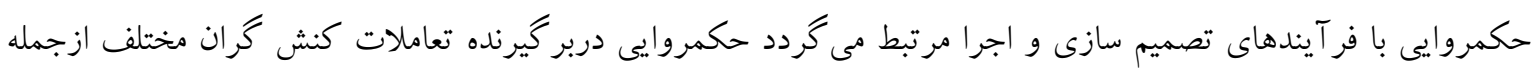

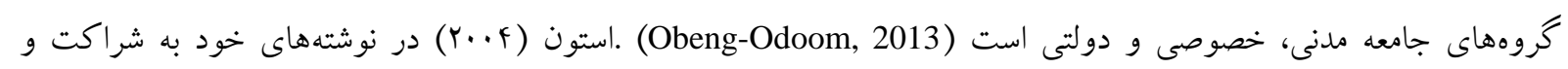

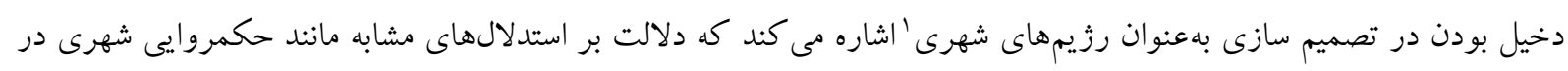

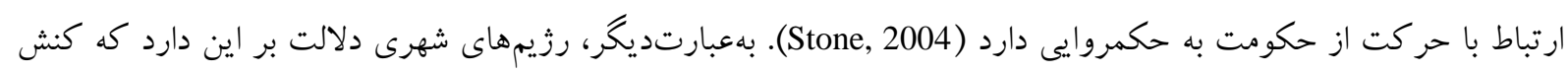

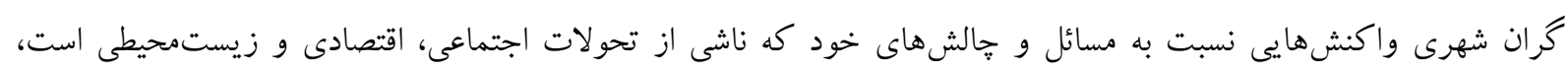

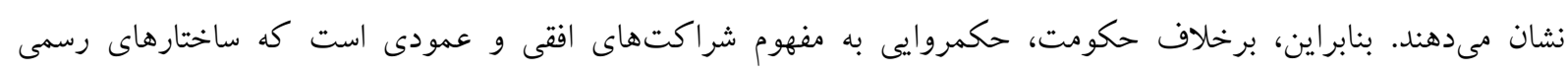

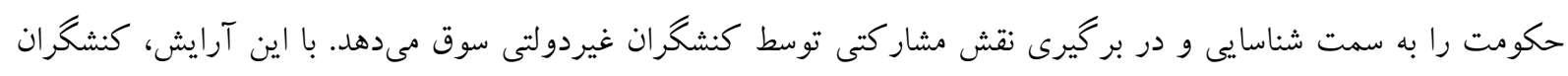

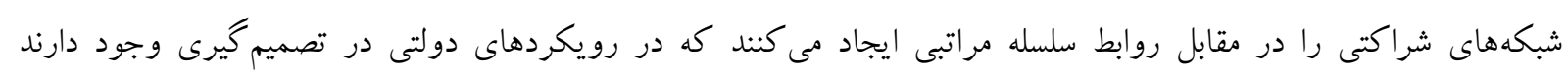
.(Kennedy, 2008; Obeng-Odoom, 2013) همبروايى شهرى را بدين كونه تعريف مى كند: مجموع بسيارى از روشهايى كه اشخاص و سازمانها،

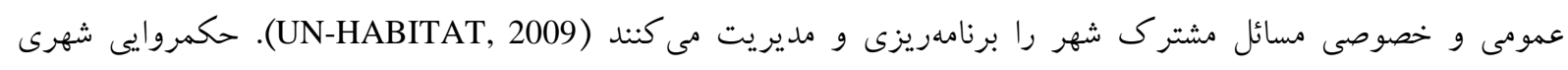

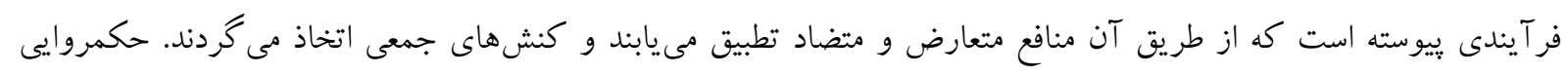

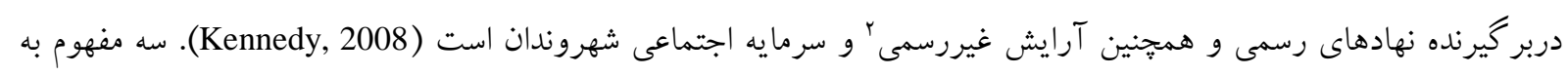

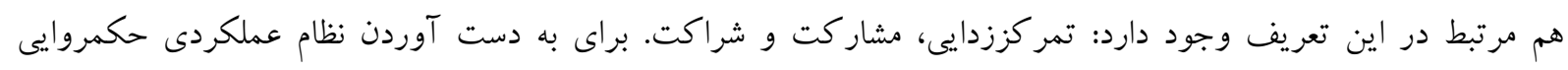

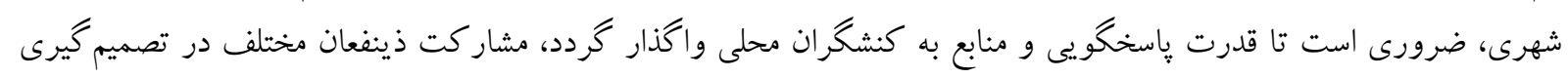

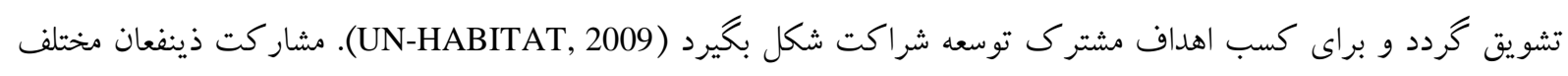

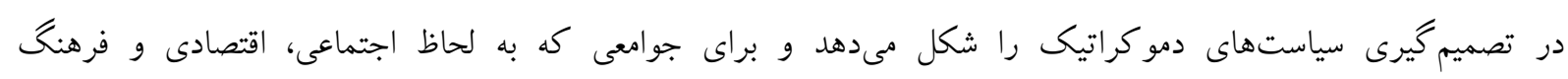

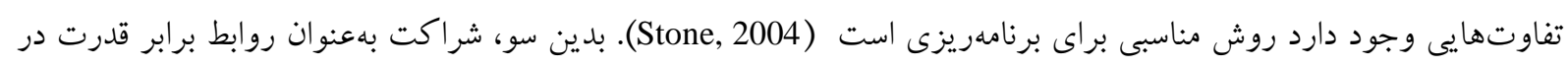

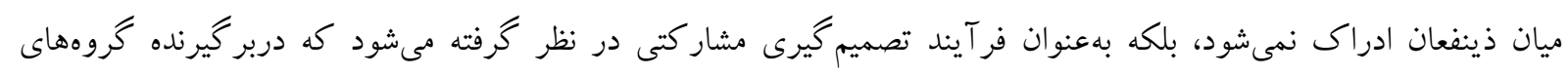
جامعه مدنى، خصوصى و دولتى در نظامهاى غيرمتمر كز حكمروايى مى باشد (Obeng-Odoom, 2013) . 


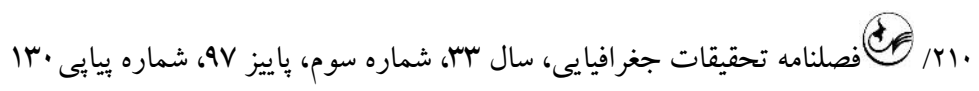

حكمروايى در باز آفرينى شهرى

حكمروايى به يك موضوع اصلى در بين سياست گذاران تبديلشده است. ازاينرو يكى اتفاقنظر بين المللى وجود دارد كه

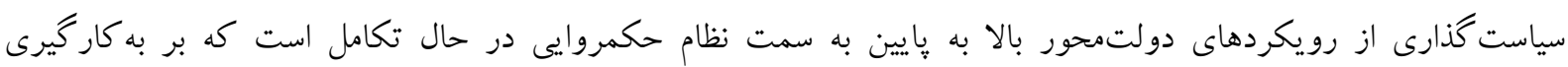

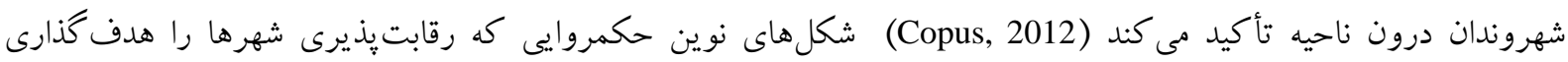

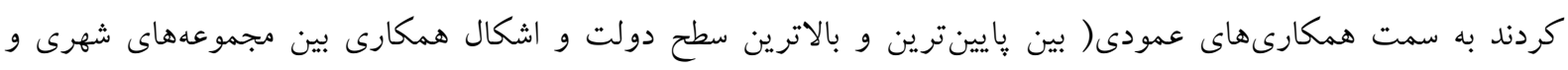

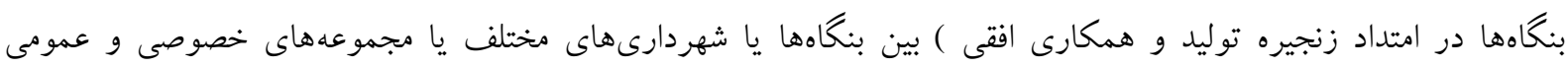

جهت گيرى كردهاند (Brenner, 2004)

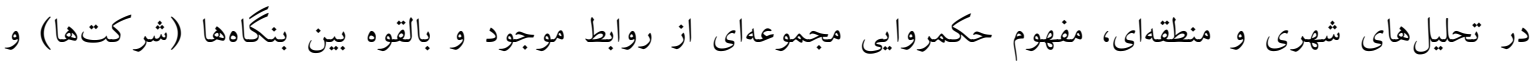

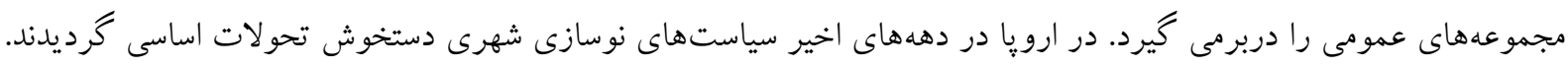

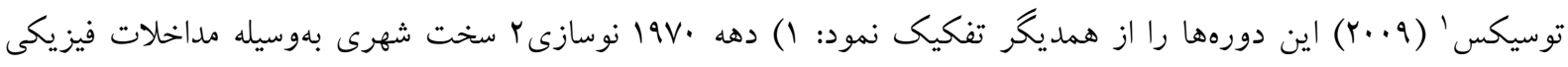

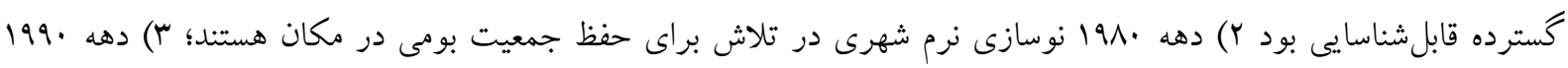

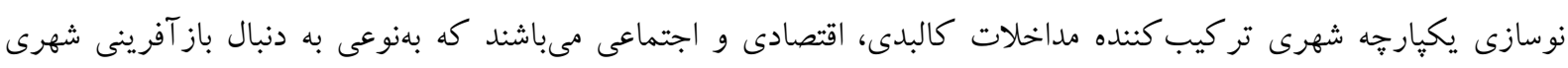

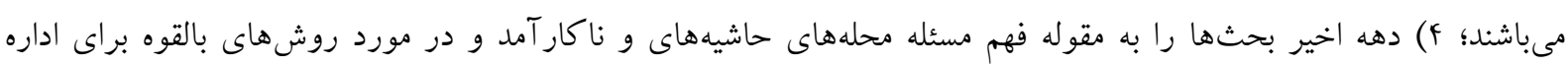

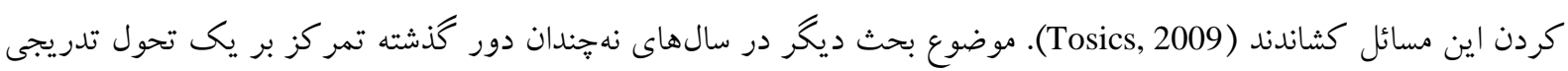

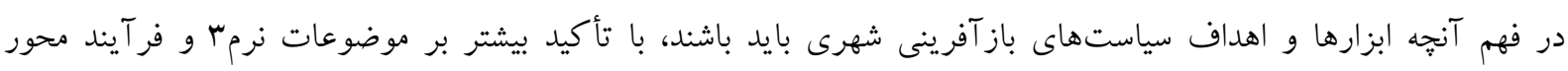

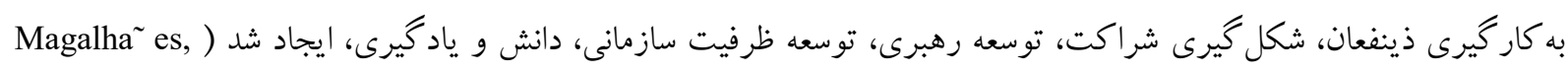

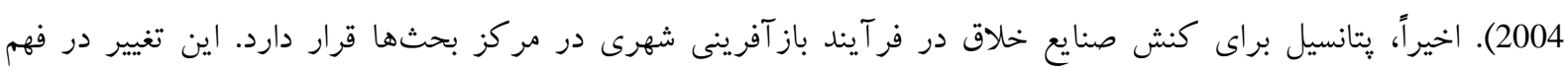

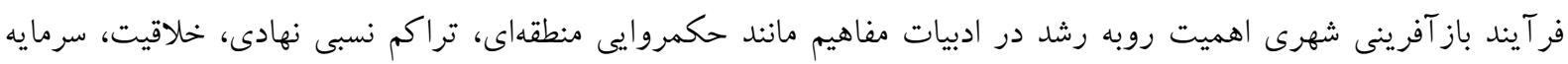

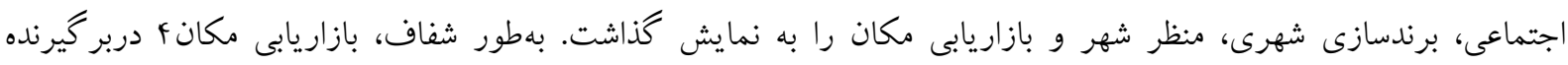

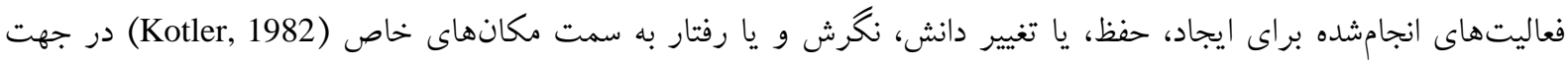

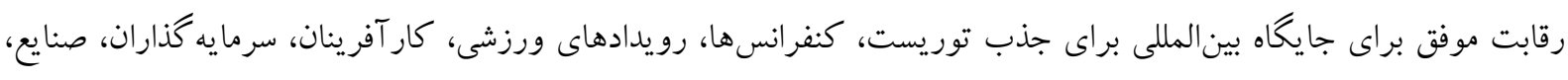

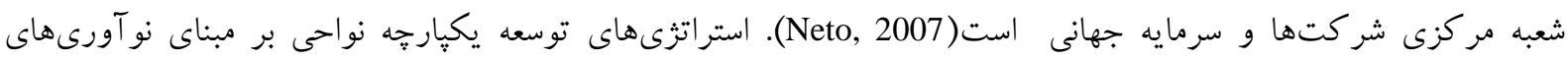

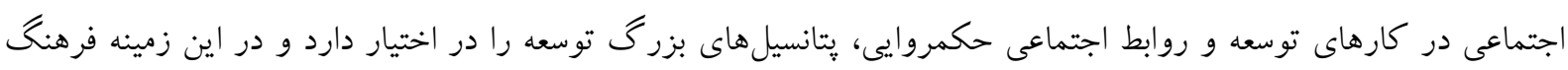

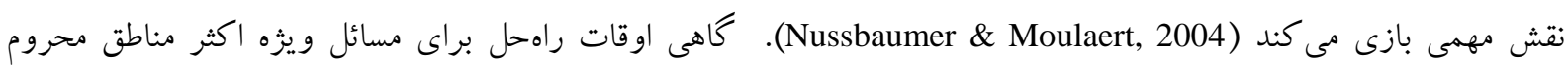

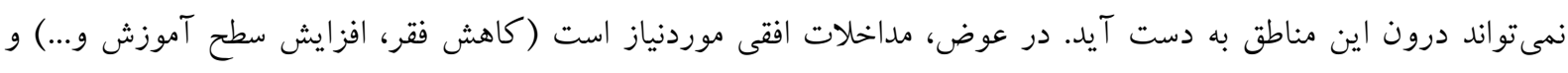

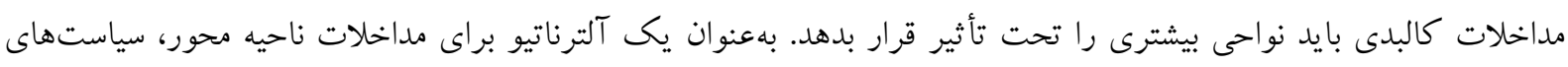

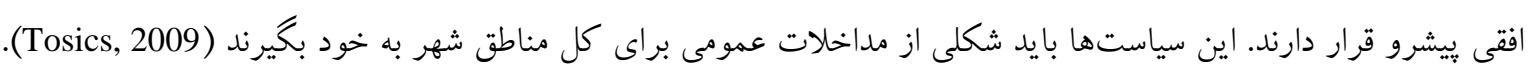

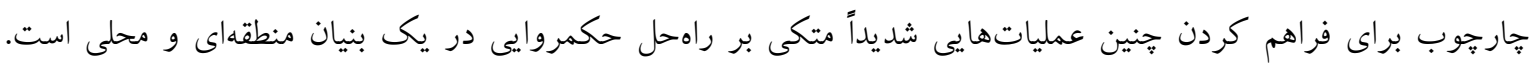

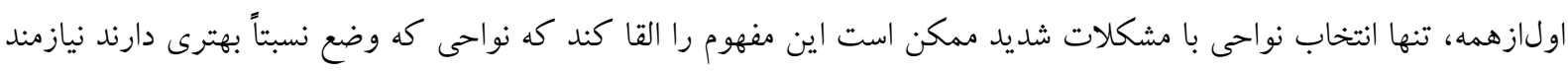

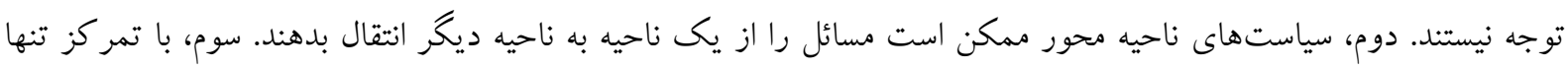

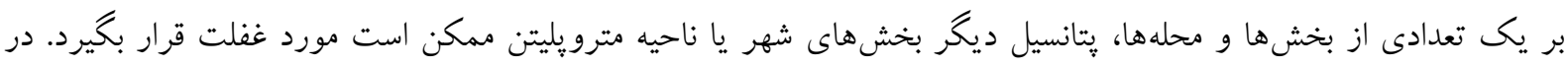


نهايت، سياست هاى ناحيه محور ممكن است فقط بخاطر بهتر قابل رويت بودن آنها مورد انتخاب واقع شوند- كه يك استدلال

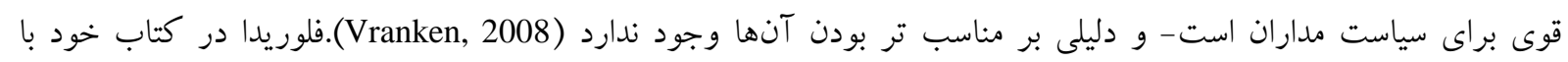

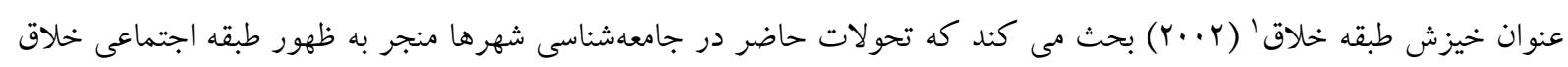

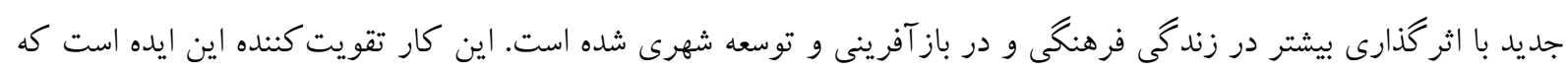

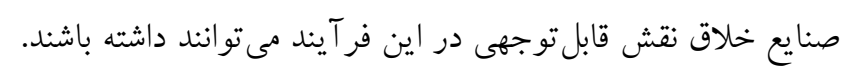

يافته هاى تحقيق

يافته هاى توصيفى

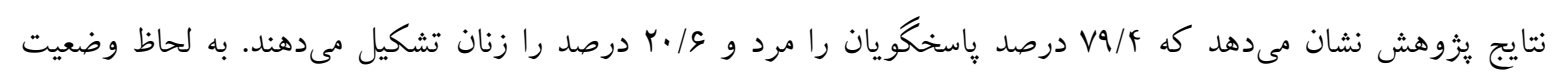

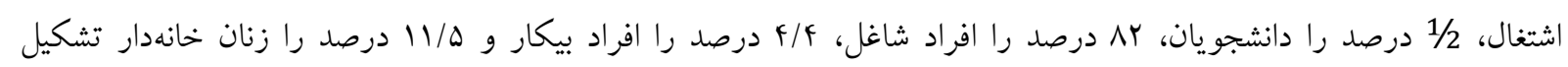

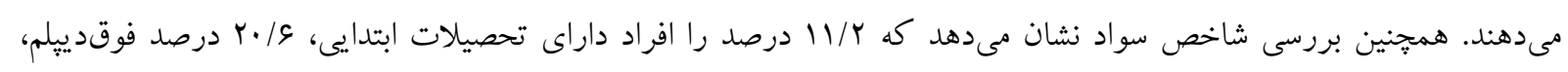

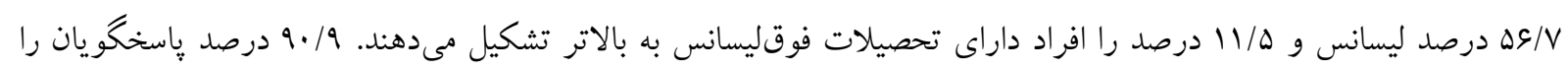

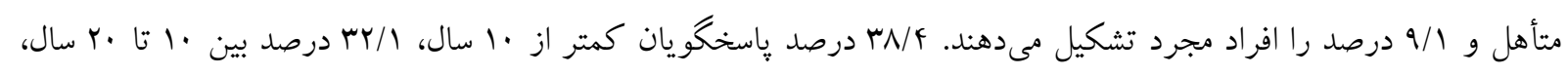

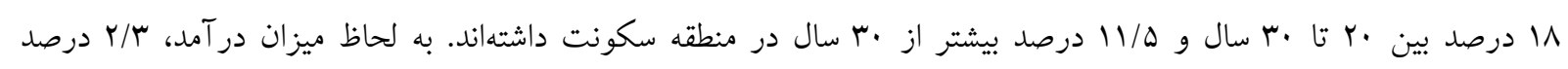

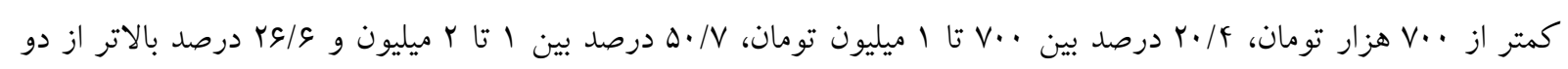

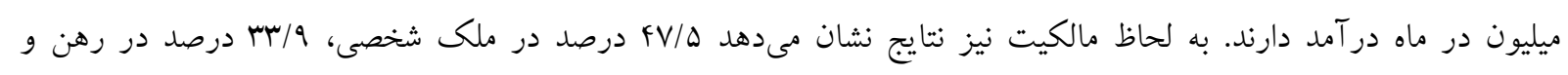

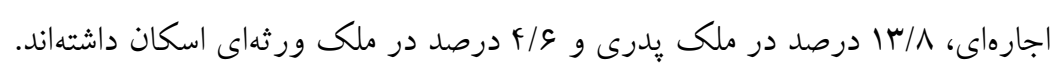

يافتهاى تحليلى

ئهت تحليل دادهها در ابتدا لازم به ذكر است كه جهت سنجش اين مؤلفهها از طيف ليكرت استفادهشده است. نمره دهى

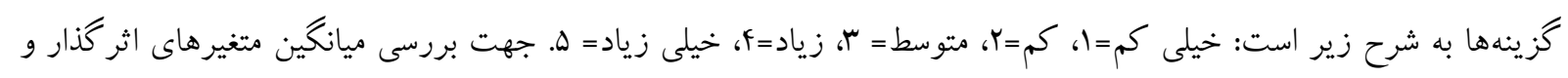

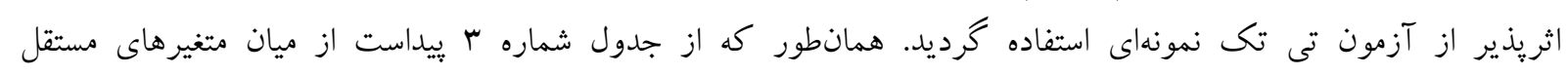

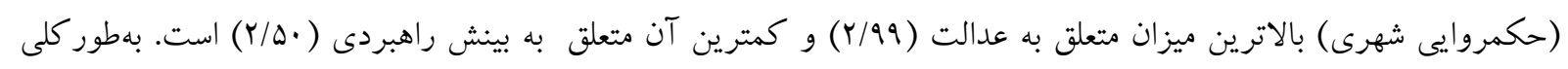

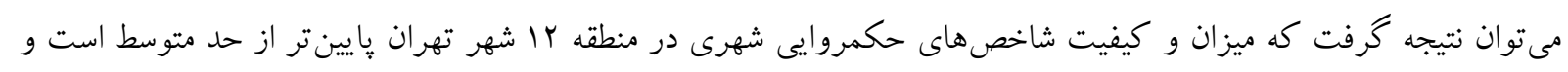

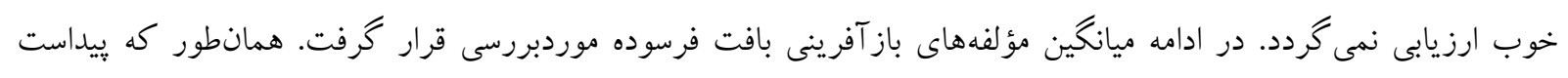

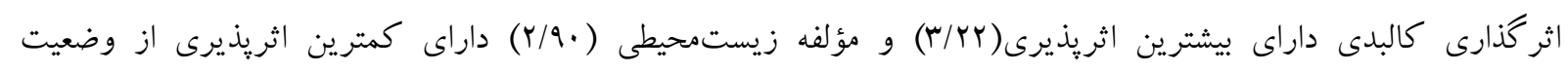

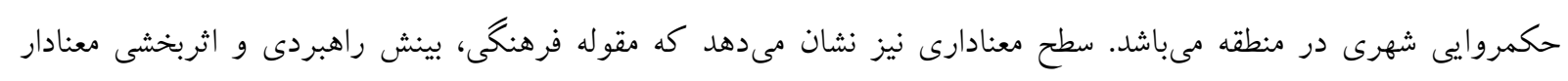

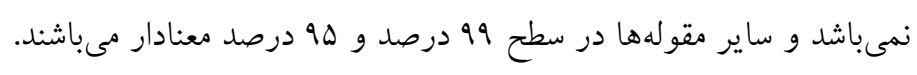

جدول r- مقايسه ميانغين متغيرهاى مستقل و وابسته

\begin{tabular}{|c|c|c|c|c|c|}
\hline سطح معنادارى & Tمون T T & انحراف معيار & ميانكين & & \\
\hline$\cdot / \cdots$ & $-\mid r / \cdot 1$ & $1 / \cdot \lambda r$ & $r / \pi r$ & مشار كت & \\
\hline$\cdot / \cdots$ & $-N / \Delta 9$ & $1 / r$ T & $r / F \Delta$ & ياسخكويى & متغير \\
\hline$\cdot / \cdot f$ & $-Y / \Lambda S$ & . /Arq & $r / A V$ & قانونمدارى & مستقل \\
\hline$\cdot / \cdot f$ & $-r / F V$ & $1 / . r f$ & $r / A S$ & شفافيت & \\
\hline
\end{tabular}

1 The Rise of Creative Class 


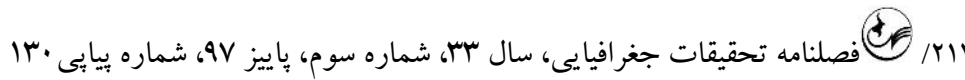

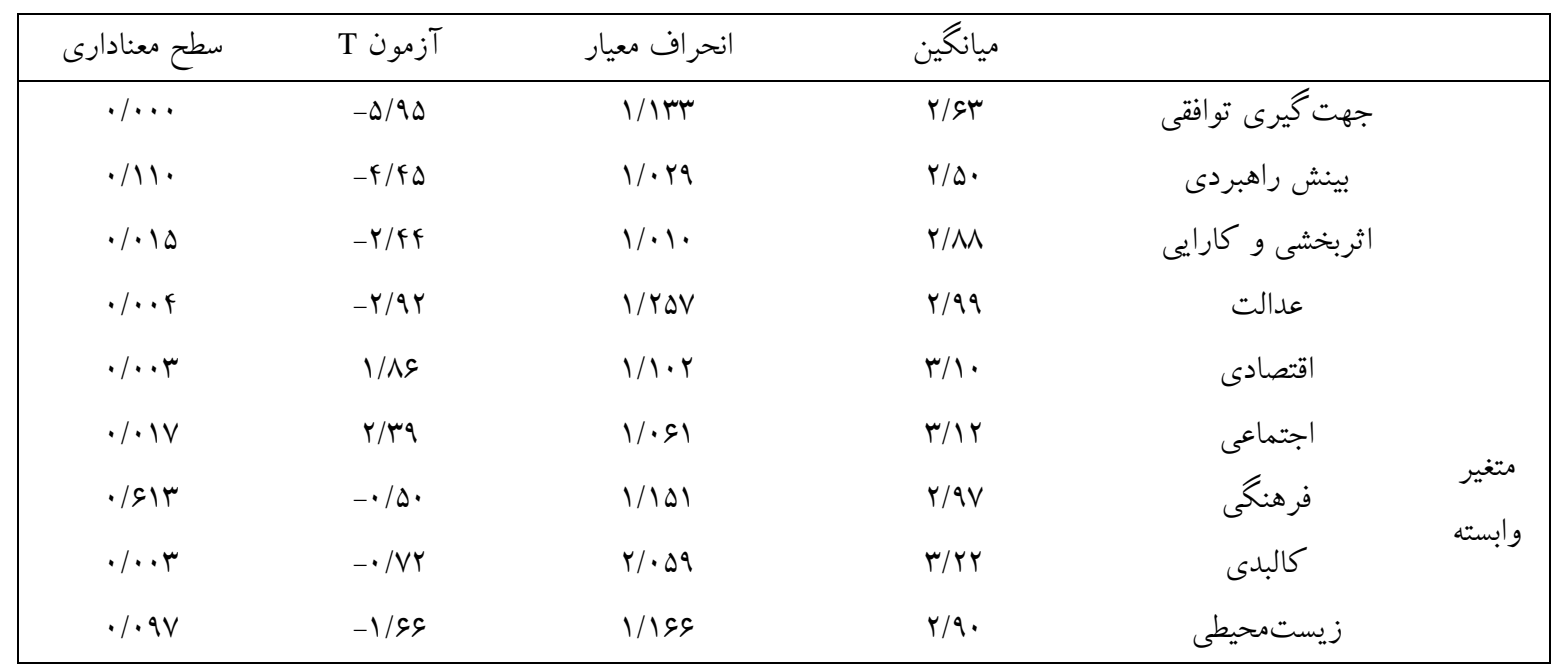

مأخذ: يافتهاى تحقيق، ITqV

سنجش اثرات مؤلفههاى فرآيند باز آفرينى از طريق حكمروايى شهرى

ارتباط بين باز آفرينى بافت فرسوده شهرى با مؤلفهاى حكمروايى شهرى بهصورت كلى سنجش و ارزيابى مى گردد.

رابطه مؤلفه مشار كت با باز آفرينى بافت فرسوده

مؤلفه مشار كت در باز آفرينى بافت فرسوده شهرى در اين مؤلفه حاصل متغير تركيبى \& سنجه است. نتايج حاصل از آزمون

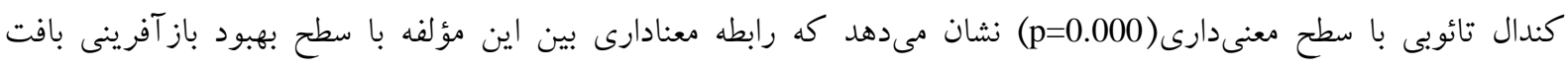
فرسوده وجود دارد.

رابطه مؤلفه ياسخكو يى با باز آفرينى بافت فرسو ده مؤلفه קاسخكويى در باز آفرينى بافت فرسوده شهرى در اين مؤلفه حاصل متغير تر كيبى f سنجه است. نتايج حاصل از از

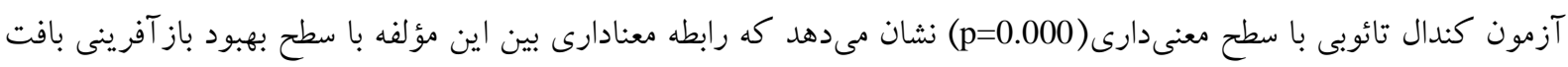
فرسوده وجود دارد.

رابطه مؤلفه قانونمدارى با باز آفرينى بافت فرسوده

مؤلفه قانونمدارى در باز آفرينى بافت فرسوده شهرى در اين مؤلفه حاصل متغير تركيبى ه سنجه است. نتايج حاصل از

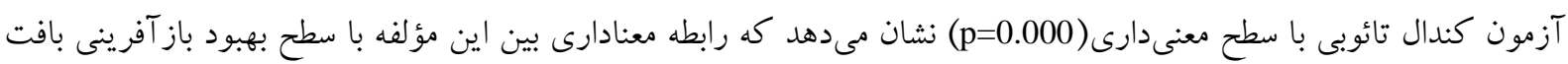
فرسوده وجود دارد.

رابطه مؤلفه شفافيت با باز آفرينى بافت فرسوده

مؤلفه شفافيت در باز آفرينى بافت فرسوده شهرى در اين مؤلفه حاصل متغير تركيبى ه سنجه است. نتايج حاصل از آزمون

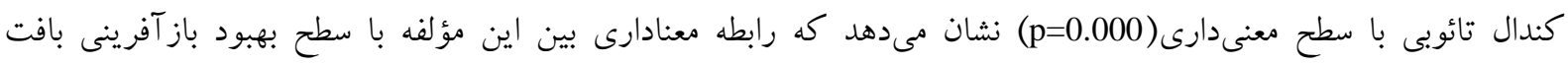
فرسوده وجود دارد. 
رابطه مؤلفه جهت گيرى توافقى با باز آفرينى بافت فرسوده

مؤلفه جهت گيرى توافقى در باز آفرينى بافت فرسوده شهرى در اين مؤلفه حاصل متغير تركيبى لإسنجه است. نتايج حاصل

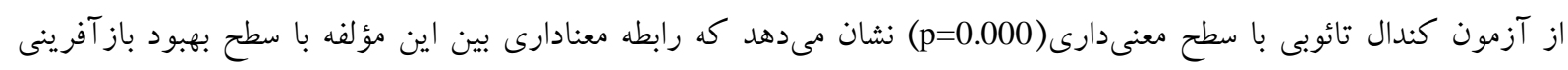

$$
\text { بافت فرسوده وجود دارد. }
$$

\section{رابطه مؤلفه بينش راهبردى با باز آفرينى بافت فرسوده}

مؤلفه بينش راهبردى در باز آفرينى بافت فرسوده شهرى در اين مؤلفه حاصل متغير تركيبى ب سنجه است. نتايج حاصل از

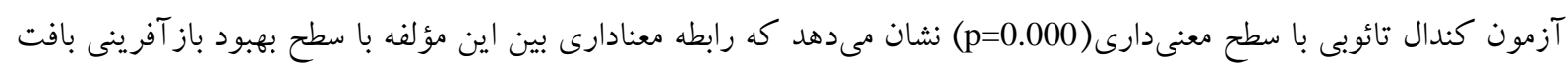
فرسوده وجود دارد.

رابطه مؤلفه اثربخشى و كارايى با باز آفرينى بافت فرسوده

مؤلفه اثربخشى و كارايى در باز آفرينى بافت فرسوده شهرى در اين مؤلفه حاصل متغير تركيبى ه سنجه است. نتايج حاصل

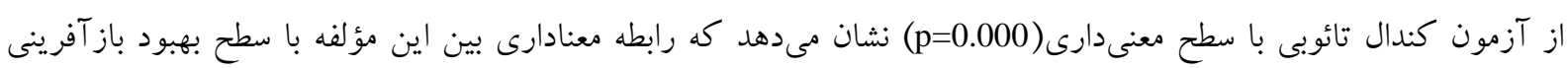

$$
\text { بافت فرسوده وجود دارد. }
$$

\section{رابطه مؤلفه عدالت با باز آفرينى بافت فرسوده}

مؤلفه عدالت در باز آفرينى بافت فرسوده شهرى در اين مؤلفه حاصل متغير تركيبى r سنجه است. نتايج حاصل از آزمون

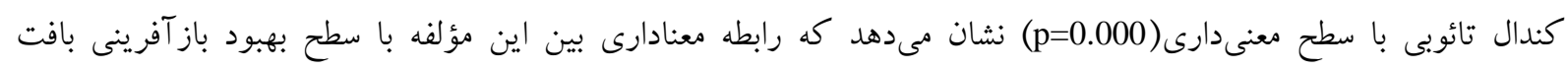
فرسوده وجود دارد.

\begin{tabular}{|c|c|c|c|c|c|c|}
\hline \multirow{2}{*}{ وجود رابطه } & \multicolumn{2}{|c|}{ Kendall's tau_b tes } & \multirow[t]{2}{*}{$\mathrm{Sd}$} & \multirow{2}{*}{ مؤلفه اثريذير } & \multirow{2}{*}{ مؤلفه هاى اثر گذار } & \multirow{2}{*}{ رديف } \\
\hline & Sig & $\mathrm{r}$ & & & & \\
\hline دارد & $\cdot / \cdots$ & $\cdot /$ TYA & - /VAYVY & & مشار كت & 1 \\
\hline 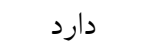 & $\cdot / \cdots$ & $\cdot / r \Lambda F$ & $\cdot|A F F \Lambda|$ & & شفافيت & r \\
\hline دارد - ارد & $\cdot / \cdots$ & $\cdot /$ rNT & . /QDFFF & باز آفرينى بافت & قانونمدارى & $r$ \\
\hline 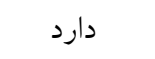 & $\cdot / \cdots$ & . Mtrt & . /91KKF & فرسوده & مسئوليت يذيرى و ياسخگويى & f \\
\hline دارد & $\cdot / \cdots$ & $\cdot|r|$. & $1 / \cdot \cdot 1 \cdot r$ & & بينش راهبردى & $\Delta$ \\
\hline دارد & $\cdot / \cdots$ & $\cdot / \Delta \Delta 1$ & ./MAs.. & & جهت كيرى توافقى & s \\
\hline دارد & $\cdot / \cdots$ &.$/ T r$. & ./VVq.. & & اثربخشى و كارايى & v \\
\hline دارد &.$/ \ldots$ & $\cdot / r V q$ & - /VSA. & & عدالت & $\wedge$ \\
\hline
\end{tabular}

جدول F- رابطه بين مؤلفههاى حكمروايى شهرى با باز آفرينى شهرى

مأخذ: يافتهاى تحقيق، IraV

\section{ارتباط بين فر آيند باز آفرينى از طريق حكمروايى خوب شهرى}

سنجش رابطه بين فرآيند بازآفرينى از طريق حكمروايى شهرى كه دربر گيرنده 1 مؤلفه است، با توسعه نظام اجتماعى،

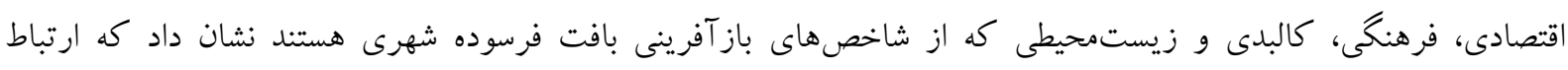

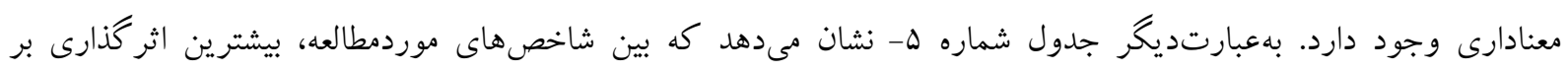




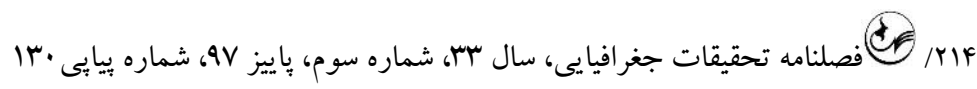

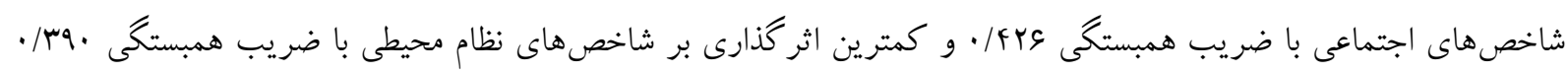
مشاهده مى گردد.

جدول هـ ارتباط بين فر آيند باز آفرينى از طريق حكمروايى خوب شهرى

\begin{tabular}{|c|c|c|c|c|c|}
\hline \multirow[t]{2}{*}{ وجود رابطه } & \multicolumn{2}{|c|}{ Kendall's tau_b tes } & \multirow[t]{2}{*}{ مؤلفه اثر كذار } & \multirow[t]{2}{*}{ مؤلفه هاى اثريذير } & \multirow[t]{2}{*}{ رديف } \\
\hline & sig & $\mathrm{r}$ & & & \\
\hline دارد & $\cdot / \cdots$ & $* * \cdot / f \mid r$ & & نظام اقتصادى & 1 \\
\hline دارد & $\cdot / \cdots$ & $* * \cdot / r q \Lambda$ & حكمروايى شهرى & نظام اجتماعى & r \\
\hline دارد & $\cdot / \cdots$ & $* * . / \Gamma \wedge \Delta$ & & نظام فرهنكى & $r$ \\
\hline دارد & $\cdot / \cdots$ & ***/rs| & & نظام كالبدى & f \\
\hline ن ل & $\cdot|| r \mid$ & $* * / \Gamma \Delta 1$ & & نظام زيست محيطى & $\Delta$ \\
\hline
\end{tabular}

مأخذ: يافته هاى تحقيق، ITYV

$$
\text { ارزيابى نهايى تأثير حكمروايى شهرى در باز آفرينى بافت فرسوده شهرى }
$$

براى تعيين شدت ميزان همبستكى تعداد ^ مؤلفه اثر كذار حكمروايى شهرى در ارتباط با مؤلفه اثريذير باز آفرينى بافت

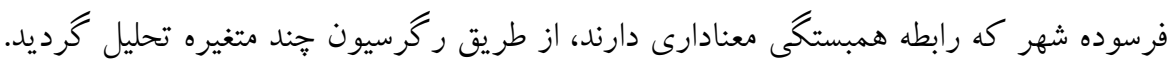

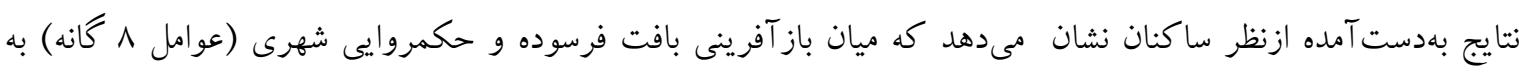

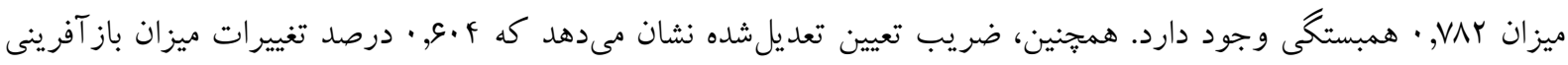

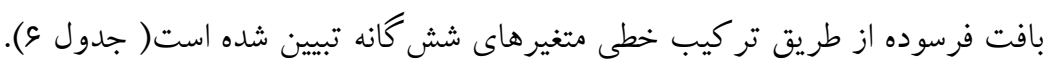
جدول و- نتايج ركرسيون متغيرهاى اصلى هشت كانه در ارتباط با بر آيند باز آفرينى بافت فرسوده شهرى از ديدكاه ساكنان

\begin{tabular}{|c|c|c|c|c|}
\hline اشتباه معيار & ضريب تعيين تعديلشده & ضريب تعيين R & ضريب همبستكى جند گانه & مدل \\
\hline 0.69190 & 0.604 & 0.611 & $\frac{\Lambda}{0.782 \quad \mathrm{a}}$ & 1 \\
\hline
\end{tabular}

A predicators: مشار كت، پِاسخگويى، قانونمدارى، شفافيت، جهت گيرى توافقى، بينش راهبردى، عدالت، اثربخشى همجنين، بر اساس مقدار محاسبهشه براى F، در سطح اطمينان 9 ودرصد، مىتوان كفت كه از ديد كاه ساكنان بافت فرسوده تركيب خطى متغيرهاى مستقل بهطور معنادارى قادر به تبيين و بيشبينى تغييرات متغير وابسته باز آفرينى بافت فرسوده

$$
\text { است (جدول شماره V). }
$$

جدول V- معنادارى ركرسيون متغيرهاى اصلى هشت كانه بر متغير بر آيند باز آفرينى بافت فرسوده شهرى از ديد

\begin{tabular}{|c|c|c|c|c|c|c|}
\hline سطح معنادارى.sig & $\mathrm{F}$ & ميانكين مربعات & $\begin{array}{c}\text { درجه آزادى } \\
\text { Df }\end{array}$ & مجموع مربعات & & مدل \\
\hline \multirow[t]{3}{*}{$\mathrm{a} \cdot / \cdots$} & $q r, \& \vee q$ & $F F, \wedge F$ & $\varepsilon$ & $r \& q, \cdot v \wedge$ & اثر رگرسيونى & 1 \\
\hline & & $\cdot, F \vee q$ & $r \Delta \Lambda$ & $|V|, r \wedge f$ & باقيمانده & \\
\hline & & & ref & $F F \cdot$ FEY & كل & \\
\hline
\end{tabular}
ANOVA (b)

A predicators: مشار كت، ياسخگگيى، قانونمدارى، شفافيت، جهت گيرى توافقى، بينش راهبردى، عدالت، اثربخشى

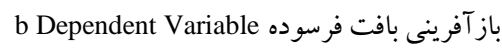


در نهايت، بر اساس ضريب استانداردشده تأثير متغيرهاى مستقل بر متغير وابسته، نتايج در باز آفرينى بافت فرسوده از طريق

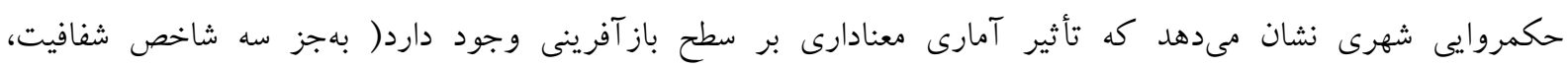

قانونمدارى و بينش راهبردى).

جدول ^- ضرايب ميزان شدت اثركذارى متغيرهاى مستقل بر متغير وابسته از ديدكاه ساكنان

\begin{tabular}{|c|c|c|c|c|c|c|}
\hline \multirow{2}{*}{ سطح معنادارى.sig } & \multirow{2}{*}{$\mathrm{t}$} & \multirow{2}{*}{ 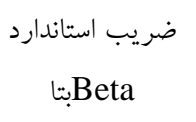 } & \multicolumn{2}{|c|}{ ضريب غيراستاندارد } & & \multirow{2}{*}{ ل ال مدل } \\
\hline & & & Std. Error & B & & \\
\hline$\cdot, \cdots$ & $\vee, \Delta v q$ & & $\cdot, \mid S T$ & $1, \Gamma \wedge \mu$ & عرض از مبدأ & 1 \\
\hline$\cdot, \cdots$ & $-\gamma$, rar & $-\cdot, f \uparrow \varepsilon$ & $\cdot, .48$ & $-\cdot, f \wedge \cdot$ & مشار كت & r \\
\hline$\cdot$, rYA & $\cdot, 4 \wedge$. & ג & $\cdot, r q$ & $\cdot, r q$ & شفافيت & $r$ \\
\hline$\cdot$, Tra & r, TDF & - & $\cdot, \cdot v 9$ & $\cdot, \mathrm{IVV}$ & قانونمدارى & f \\
\hline$\cdot, \cdot f$. & $-r, \cdot G r$ & $-\cdot, 118$ & $\cdot, \infty$ & $-\cdot, 1 \cdot r$ & هِاسخكويى & a \\
\hline$\cdot, \pi r$. & $f, \Delta \Delta r$ & · 194 & 每 & $\cdot, 1+9$ & بينش راهبردى & $\varepsilon$ \\
\hline$\cdot, \cdots$ & $1 f, 99 \mathrm{~V}$ & · & $\cdot, \Delta f$ & $\cdot, \wedge \cdot \cdot$ & جهت گيرى توافقى & v \\
\hline$\cdot, \cdots$ & $f, \Delta \Delta r$ & $\cdot, 194$ & ( & $\cdot, 1 \mp 9$ & اثربخشى و كارايى & $\wedge$ \\
\hline$\cdot, \cdots$ & $F, \Delta V Y$ & $\cdot$, זSS & $\cdot,+F V$ & $\cdot$, YYA & عدالت & 9 \\
\hline
\end{tabular}

منبع: يافته هاى تحقيق

\section{نتيجه گيرى}

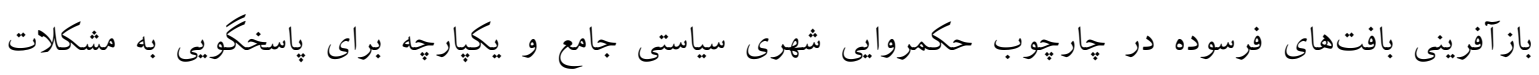

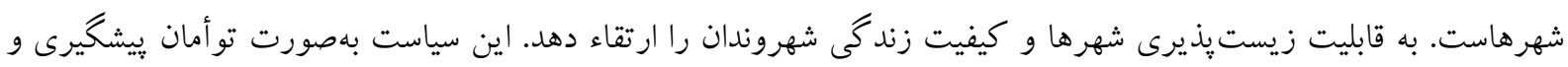

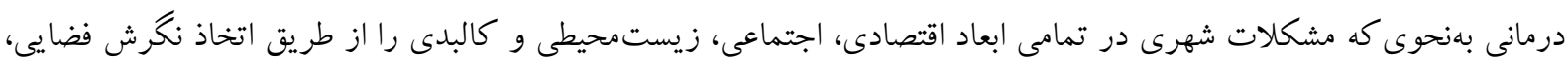

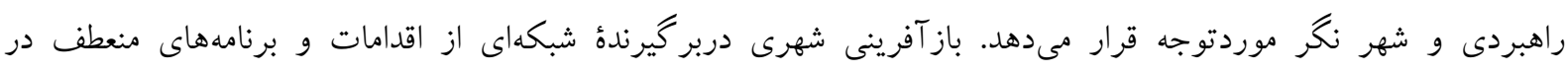

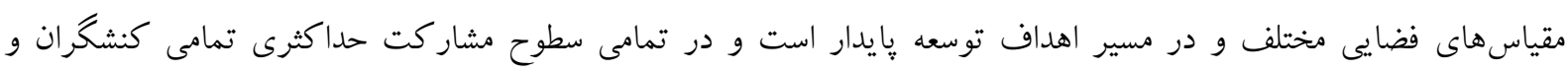

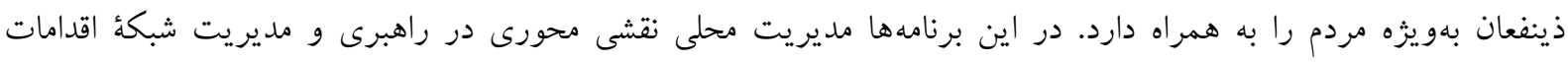

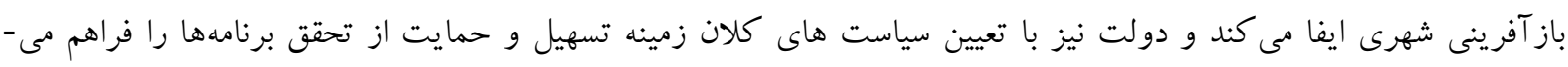

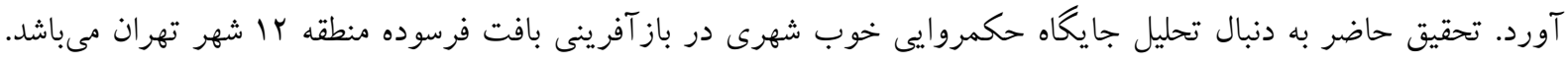

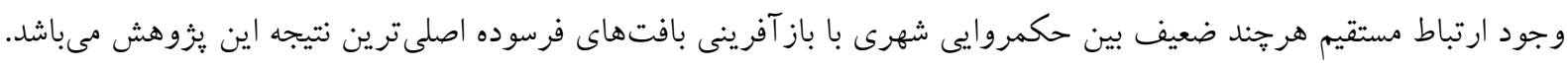

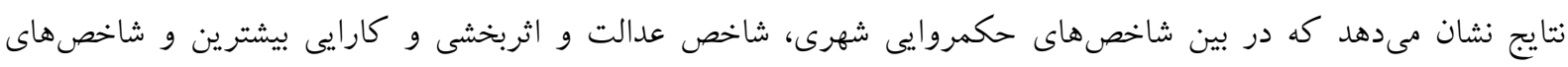

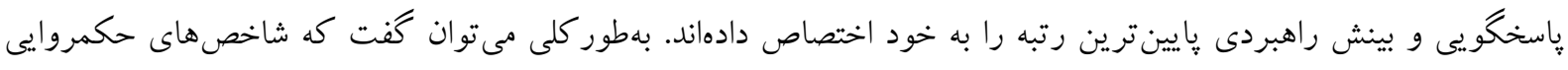

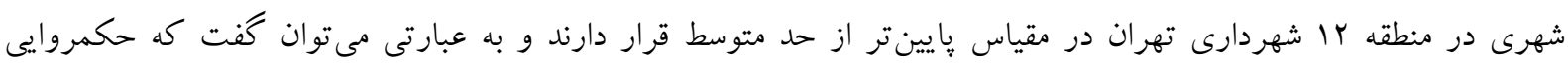

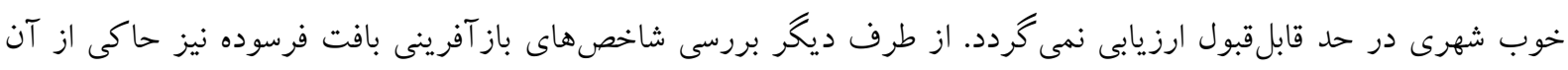

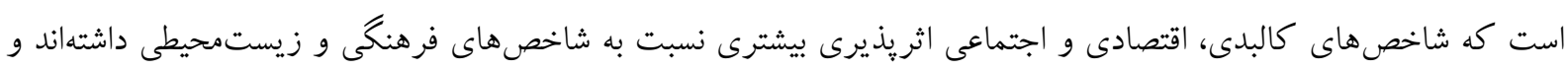

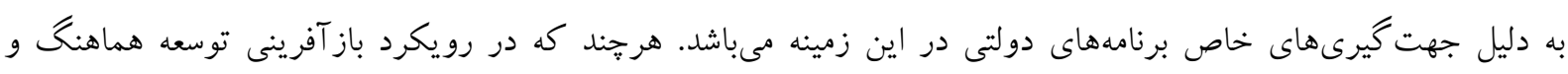

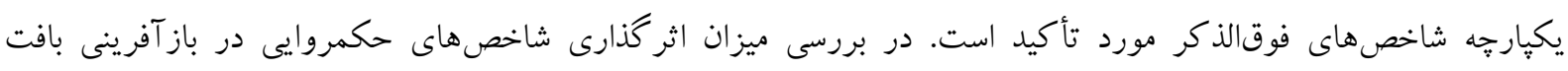

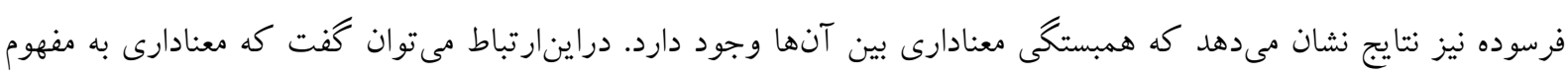




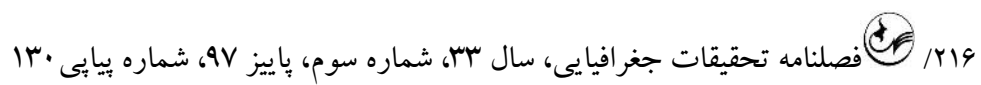

اثر كذارى قابلتوجه نيست (هرجند در مقياس كم تأثيراتى داشته است) بلكه يايين بودن سطح شاخصهاى حكمروايى و بازآفرينى نقش مهمى در معنادارى اين آزمون ايفا مى كند و در نهايت شاخصهاى شفافيت، قانونمدارى و بينش راهبردى قادر به تبيين بازآفرينى شهرى در منطقه موردمطالعه نشدند. در جايشاه مقايسه، نتايج اين يزوهش باكار عظيمى و جمع دار Azimi Amoli \& Jamdar, ) هوسا) همسو است كه به وضعيت نامناسب حكمروايى خوب شهرى در محله ده ونك اشاره دارد 2016). همجنين با نتايج يزوهش عظيمى و همكاران(سوسا) در مورد بين ارتباط ميزان مشاركت مردم و روند نوسازى بافت هاى فرسوده در شهر خالوس همسو مىباشد (Azimi Amoli, Alkaei, \& Tabrizi, 2014). در بعد حكمروايى شهرى، نتايج

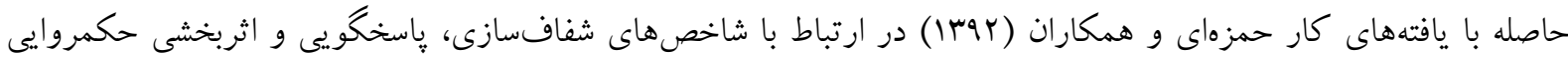
خوب در شهردارى مشهد همسو مىباشد (Hamzeyee, Baradaran, \& Hatefi, 2013). همجنين يافتهاى اين يزوهش بامطالعه رهنما و اسدى (سوس ا) در ارتباط با وضعيت نامناسب حكمروايى در شهردارى مشهد همسو مىباشد ) Rahnama \& Asadi,

$$
\begin{aligned}
& \text { 2014). در راستاى بهبود جايشاه حكمروايى شهرى در باز آفرينى شهرى برخى ييشنهادها به شرح زير مطرح مى گردد: } \\
& \text { توجه به نيازهاى گروههاى مختلف جمعيت در مديريت برنامهريزى بافت فرسوده } \\
& \text { تجديدنظر در رويكردهاى مديريت شهرى در راستاى جلب مشاركت مردم در فر آيند باز آفرينى بافت فرسوده، }
\end{aligned}
$$

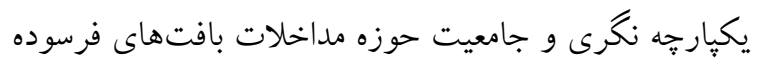

$$
\begin{aligned}
& \text { كاهش فاصله بين مردم و نهادهاى مديريتى - اجرايى فعال در زمينه باز آفرينى بافت فرسوده } \\
& \text { دخيل نمودن واقعى مردم در فر آيند برنامهريزى و شكل كيرى الخوى برنامهريزى با مردم } \\
& \text { شفافسازى مديران و افزايش حس ياسخخويى نسبت به اقدامات و عملكردها }
\end{aligned}
$$

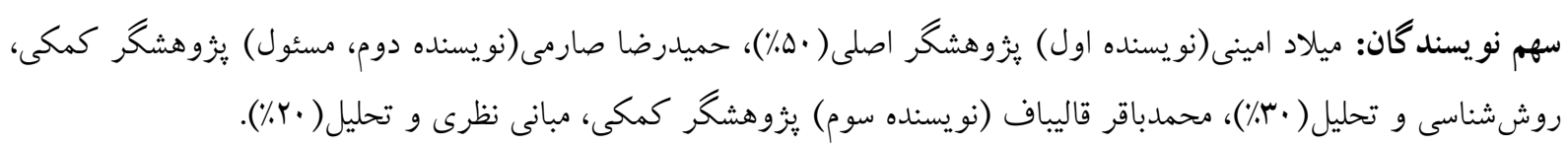

اين مقاله بركرفته از رسالهى دكترى ميلاد امينى با عنوان ارائه الكوى حكمروايى مطلوب در فرايند باز آفرينى بافت فرسوده

$$
\text { شهرى (موردمطالعه: منطقه rا شهر تهران) دانشكده هنرومعمارى دانشخاه تربيت مدرس مىباشد. }
$$

$$
\text { منابع و مآخذ }
$$

Adams, D., \& Hastings, E. M. (2001). Urban renewal in Hong Kong: transition from development corporation to renewal authority. Land Use Policy, 18(3), 245-258. [DOI:10.1016/S0264-8377(01)00019-9]

Aeeni, M., \& Ardestani, Z. (2009). Pyramid regeneration and people participation, evaluation criteria for urban development plans. Urban identity Quarterly, 3(5), 47-58. (Persian)

Ahmadpour, A., Habibi, K., \& Keshavarz, M. (2010). The evolution of the concept of urban regeneration as a new approach in urban exhausted textures. Quarterly Journal of Iranian Islamic Studies, 1(1), 73-92. (Persian)

Azimi Amoli, J., Alkaei, H., \& Tabrizi, N. (2014). Renovation of urban textile tissues with a public participation approach; case study: 6th district of Chaloos. New Attitudes in Human Geography, 7(1), 145-166. (Persian)

Azimi Amoli, J., \& Jamdar, A. (2016). Regeneration of worn-out urban textures with urban good governance approach (case study: Deh-e- Vanak district). Journal of Regional Planning, 25(2), 85-99. (Persian)

Brenner, N. (2004). New state spaces: Urban governance and the rescaling of statehood (First ed.). Oxford: Oxford University Press.

Copus, C. (2012). The role of local governance in Europe. Panorama: Insights into Asian and European Affairs, 2,2012 
TlV/.... جايكاه حكمروايى شهرى در فر آيند باز آفرينى بافت فرسوده شهرى

Dert, A. (2000). By desing: Urban desing in the planning system. London: Towards Better Practice.

Fallahzadeh, S., \& Mahmoudi, F. (2015). Prioritizing participatory policies in urban regeneration with emphasis on the probability of conflict among key stakeholders (case study: Old part of Amol urban regeneration plan). Quarterly Journal of Urban studies of Kurdistan University, 4(15), 5-16. (Persian)

Habibi, K., Pour Ahmad, A., \& Meshkini, A. (2007). Urban rehabilitation \& renovation in the old textures. Tehran: Entekhab. (Persian)

Hafeznia, M. R. (2009). An introduction to the research method in humanities. Tehran: Samt. (Persian)

Hamzeyee, M., Baradaran, M. M., \& Hatefi, F. (2013). Good governance in the municipality of Mashhad. Paper presented at the The 5th Conference on Urban Planning and Management, Mashhad. (Persian)

Kalantari Khalilabad, H., \& Pourahmad, A. (2005). Models and techniques of renovation planning of historical areas in cities. Territory, 2(3), 105-116. (Persian)

Kennedy, L. (2008). New forms of governance in Hyderabad: How urban reforms are redefining actors in the city. In I. S. A. I.S.A. Baud \& J. De Wit (Eds.), New Forms of Urban Governance in India: Shifts, Models, Networks and Contestations. India, New Delhi: SAGE Publications.

Kotler, P. (1982). Marketing for nonprofit organizations. New Jersey: Prentice-Hall. Inc.

Luda, T. (2006). E- compendium: Handbook E2, understanding large distressed areas, program energy, environment and sustainale development. Europe, European Union.

Magalha ${ }^{2}$ es, C. S. (2004). Centres of excellence for urban regeneration: promoting institutional capacity and innovation or reaffirming old ideas? Planning Theory \& Practice, 5(1), 33-47. [DOI:10.1080/1464935042000185053]

Neto, P. (2007). Strategic planning of territorial image and attractability. In A. Matias, P. Nijkamp, \& P. Neto (Eds.), Advances in Modern Tourism Research (pp. 233-256). Berlin: Springer.

Nobari, N., \& Rahimi, M. (2010). Good urban governance is an indispensable necessity. Center for Study and Planning of Tehran, Knowledge of City, 11, (Persian)

Nussbaumer, J., \& Moulaert, F. (2004). Integrated area development and social innovation in European cities. City, 8(2), 249-257. [DOI:10.1080/1360481042000242201]

Obeng-Odoom, F. (2013). Governance for pro-poor urban development: Lessons from Ghana (First ed.). London: Routledge.

Rahnama, M. R., \& Asadi, R. (2014). Determination of the status of good urban governance indicators in Mashhad. Quarterly Journal of Urban and Regional Studies, 5(20), 143-162. (Persian)

Rahnamaei, M. T., \& Keshavarz, M. (2010). A study of the pattern of good governance and the role of the government in managing the city affairs in Iran. Urban Ecology Research, 1(1), 23-55. (Persian)

Roberts, P., \& Sykes, H. (2000). Urban regeneration: A handbook. London: Sage.

Roknoddin Eftekhari, A., Azimi Amoli, J., Pourtaheri, M., \& Ahmadipour, Z. (2011). The relationship between good governance approach and sustainable rural development in rural areas of Mazandaran Province. Rural Research, 2(4), 1-34. (Persian)

Sabaqi, A. (2013). Compilation of the mechanism of urban regeneration in dealing with urban wastewater texture, Case study: Golan Shahr neighborhood of Hamedan. Quarterly Journal of Environmental Studies, 1(4), 5-79. (Persian)

Saraei, H. (1996). An introduction to research sampling. Tehran: Samt. (Persian)

Seo, J. K. (2002). Re-urbanisation in regenerated areas of Manchester and Glasgow: New residents and the problems of sustainability. Cities, 19(2), 113-121. [DOI:10.1016/S0264-2751(02)00006-9]

Stone, C. N. (2004). It's more than the economy after all: Continuing the debate about urban regimes. Journal of Urban Affairs, 26(1), 1-19. [DOI:10.1111/j.0735-2166.2004.0001.x]

Tosics, I. (2009). Dilemmas of integrated area-based urban renewal programmes. The URBACT Tribune, 27-30.

UN-HABITAT. (2009). Urban governance index (UGI) a tool to measure progress in achieving good urban governance. Retrieved from www.unhabitat.org

Vranken, J. (2008). Cities and neighborhoods in difficulties. Some propositions on people, places and policies. Paper presented at the Keynote paper for the European Council of the Ministers for Urban Development Conference, Marseille.

Yung, P. M., \& Chan, T. M. (2004). Local politics and governance. Singapore: Konrad-Adenauer-Stiftung. 